4 nordon 



\section{Method to measure the amount of WEEE generated}

Report to Nordic council's subgroup on EEE waste 
Method to measure the amount of WEEE generated

Report to Nordic council's subgroup on EEE waste

TemaNord 2009:548

(C) Nordic Council of Ministers, Copenhagen 2009

ISBN 978-92-893-1884-6

Copies: 0

Printed on environmentally friendly paper

This publication can be ordered on www.norden.org/order. Other Nordic publications are available at www.norden.org/publications

Printed in Denmark

Nordic Council of Ministers

Store Strandstræde 18

DK-1255 Copenhagen K

Phone (+45) 33960200

Fax (+45) 33960202

www.norden org

\section{Nordic Council}

Store Strandstræde 18

DK-1255 Copenhagen K

Phone (+45) 33960400

Fax (+45) 33111870

\section{Nordic co-operation}

Nordic cooperation is one of the world's most extensive forms of regional collaboration, involving Denmark, Finland, Iceland, Norway, Sweden, and three autonomous areas: the Faroe Islands, Greenland, and Åland.

Nordic cooperation has firm traditions in politics, the economy, and culture. It plays an important rol in European and international collaboration, and aims at creating a strong Nordic community in a strong Europe.

Nordic cooperation seeks to safeguard Nordic and regional interests and principles in the global community. Common Nordic values help the region solidify its position as one of the world's most innovative and competitive. 


\section{Content}

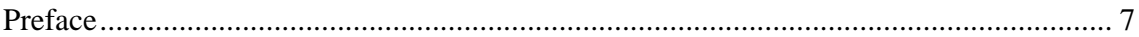

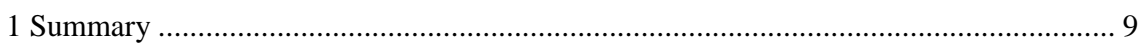

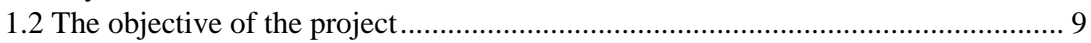

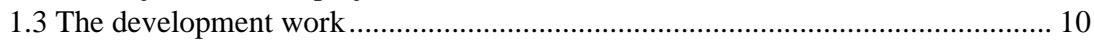

1.4 Input data and model calculation.......................................................................... 10

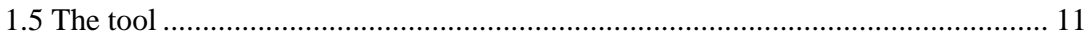

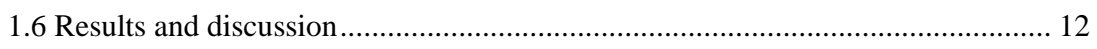

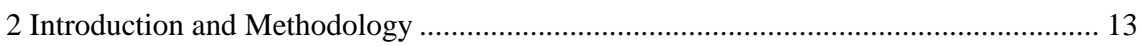

2.1 Waste of electrical and electronic products ........................................................ 13

2.2 The objective of the project............................................................................. 14

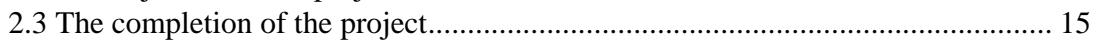

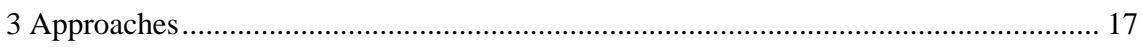

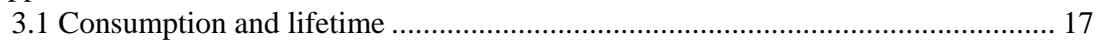

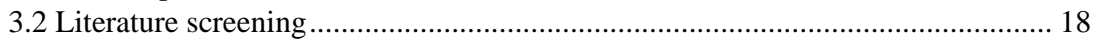

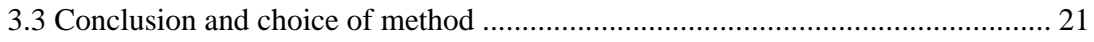

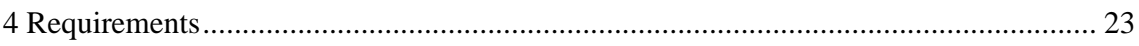

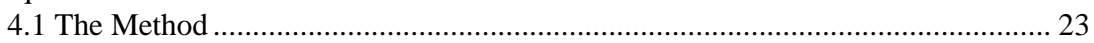

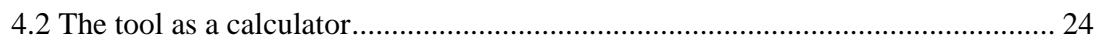

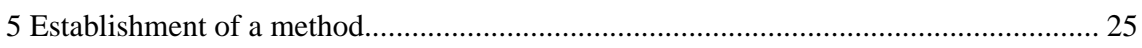

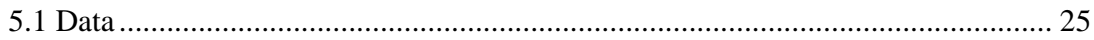

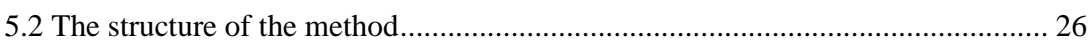

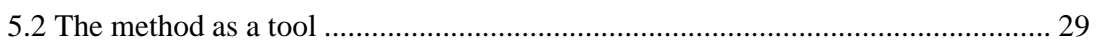

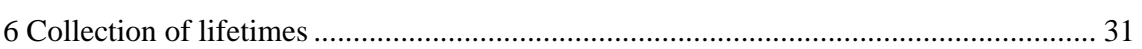

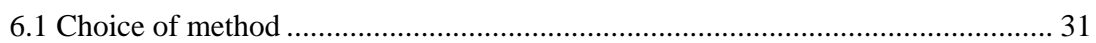

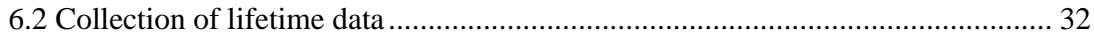

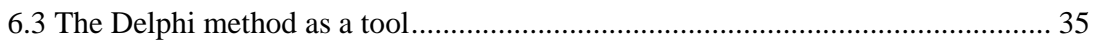

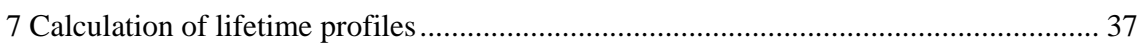

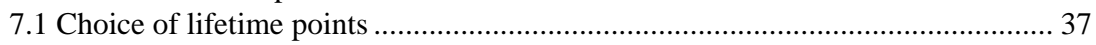

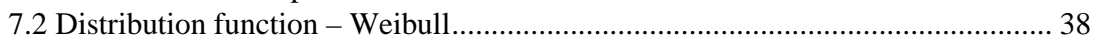

8 Collection and compiling of data on supply of EEE-products ...................................... 39

8.1 Choice of products for test calculations ............................................................ 39

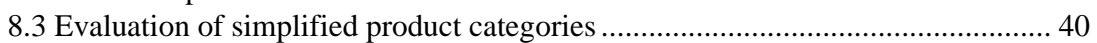

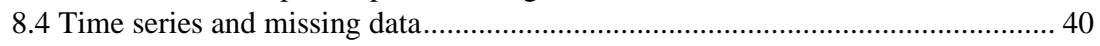

8.5 Compiling of data - step by step ...................................................................... 41

9 Evaluation of data sources on supply of EEE products ................................................ 43

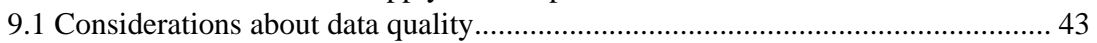

9.2 Alternative data sources for EEE products put on the market. ............................. 44

9.3 Choice of data sources in the project..................................................................... 44

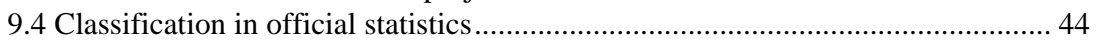

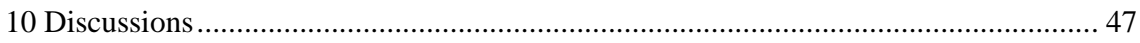

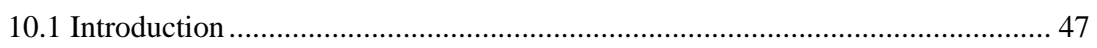

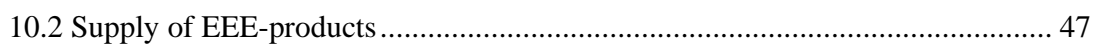

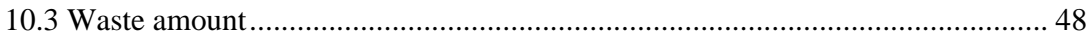

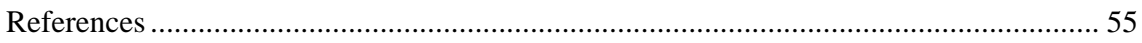




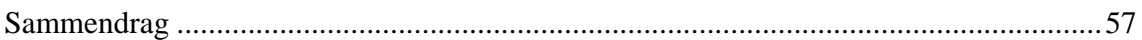

Målet med prosjektet .......................................................................................... 57

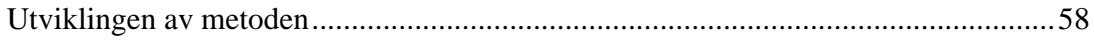

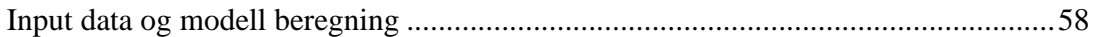

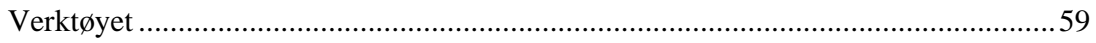

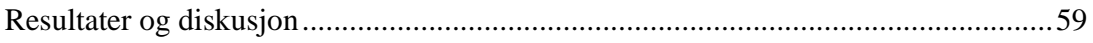

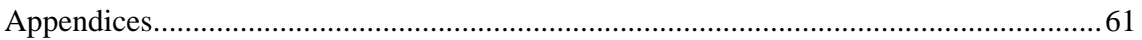

Appendix 1. Cover letter to questionnaire ………....................................................6 61

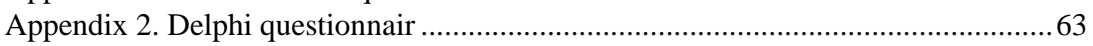

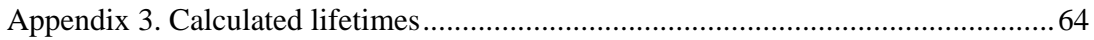

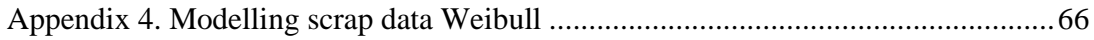

Appendix 5. EEE commodities and positions .............................................................69

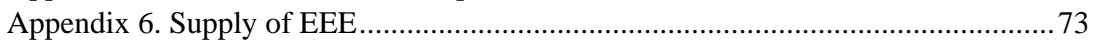

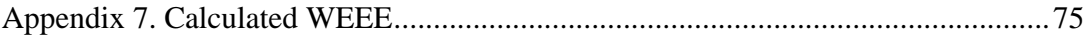




\section{Preface}

The project is initiated by The Nordic WEEE-group - a sub-group of the Product and Waste Group of the Nordic Council of Ministers (NMR). The project is financed by The Nordic Council of Ministers.

The WEEE-group consists of representatives from Denmark, Finland, Iceland, Sweden and Norway. The group had appointed a steering committee which followed the progress of the project. The committee had the following representatives:

Lena Jacobsson, Naturvårdsverket , Sweden Lis Vedel, Miljøstyrelsen, Norway Morten Carlsbcek, Miljøstyrelsen, Denmark (from 1 September 2008) Heidis Holstad Frantzen, Norway Teemu Virtanen, Finland Gunnlaug Einarsdóttir, Iceland Ole Thomas Thommesen, Norway

The project has been carried out by the consultancies Econet AS in Denmark and Mepex Consult AS in Norway. Olav Skogesal, Mepex has been project leader and responsible from Mepex Consult. Ole Kaysen has been responsible from Econet.

The project group wants to thank all persons and organizations who have kindly contributed with valuable information to the project. A special thanks to all members of the Delphi panel who assisted us by doing their best to assess life time profiles for selected EEE-products.

December 2008 



\section{Summary}

Waste of electric and electronic equipment (WEEE) consists of high amounts of hazardous and valuable materials. Consequently it has high priority to reduce the environmental problems connected with WEEE. The European Community adopted in 2003 a directive, giving the producers of Electric and Electronic Equipment (EEE) responsibility for collection and treatment of WEEE. The principle of the WEEE-directive is to improve the environmental performance of all operators involved in the life cycle of WEEE.

For compliance check and for planning and waste management purposes, the authorities and other relevant parties (producers, return schemes, operators) need to be able to predict how much WEEE is actually being generated. So far there are no good methods to calculate WEEE quantities. A method for measuring the amount of WEEE generated would also facilitate the comparison between, and exchange of experiences among countries. Finally, the amount of WEEE changes over time as a consequence of changes in the use of EEE. Consequently the figures have to be updated regularly.

\subsection{The objective of the project}

The main purpose of this project is to establish a method to measure generated Waste Electric and Electronic Equipment (WEEE). The work is financed by the Nordic Council and conducted by the consulting firms Econet AS and Mepex Consult AS.

A broad range of users is target group for the method: authorities, recovery organizations, as well as consultants and advisors. The method should be applicable to various user qualifications and it should accordingly be developed with allowance for simplicity and transparency.

The calculations are made for specified products based on historic supply to the market and the products lifetime distribution. The method has been developed for calculations on a national level according to the product categories in the EU's WEEE directive.

The method is implemented in a practical tool loaded with data from Norway. Excel has been used as software and the tool is available in a demo-version meant for documentation and demonstration, but can also be used for actual calculations when data is available.

The report is structured in such a way that it reflects the single steps and elements in the method development. The elements have been de- 
scribed briefly as the main effort has been put into development of the practical tool.

\subsection{The development work}

A literature screening has been carried out mainly in the Nordic literature in order to obtain input for the development of the method. The screening resulted with several methods - from the simple to the more complex ones. Internationally a greater work is taking place to develop methods for projecting of waste amounts generally and specifically for WEEE.

Our consumption depends on several conditions, not the least our economical capacity, but also on consumer behavior, trends, technology development and the technical function and lifetime of a product.

Knowledge about these conditions over time has been collected and taken under consideration in the method work. Only the collection of such information alone - if it is available - is a time consuming task. The same applies to current updating. If the expectations to the economical development and the consumption are taken under consideration, the modeling becomes more dynamic and complex.

More simple methods only use registered product consumption over time and estimated lifetimes with a view to calculate the waste amount. Such methods are more static in their character but are often considerably easier to update. In this project a simple method has been chosen.

\subsection{Input data and model calculation}

The method requires two types of input, which are: volumes of products supplied to the market (both historical and future) as well as lifetime distribution for individual products.

The project has examined the types of sources that can be used to provide the method with data on marketed volumes. It can be concluded that at least two sources exist, one of which is the return companies' input about marketed amounts informed by their own members. The other is the official statistics from the national statistical agencies. The difference between the two sources is partly accessibility, partly the extent of the supply amount. Because of confidentiality it can be difficult to get data from return companies and reports from return companies do not usually include free riders. These will normally be included in the official statistics. Confidentiality can also be problem related to official statistics is if the data is on a detailed level. Another problem is that the data source does not necessarily include all products or the entire amount. 
It has been chosen to recommend to use data from the national statistical bureaus, as this data is easy accessible and at the same time there is a possibility to obtain historical data.

Likewise it has been investigated how information about lifetimes of the relevant products can be collected. It has been concluded that no accessible data exists, it has to be estimated. In the project it has been chosen to collect estimates via an expert panel, which was appointed in connection with the project.

The project has used the Delphi-survey as the method, which most quickly could supply the project with lifetime data. As the method's results cannot be compared with actual knowledge, its results can alone be evaluated in comparison to what others think is probable. The method is simple and transparent, and the project recommends that the method also be used in connection with a possible updating of the current project's data.

Information about lifetimes has been collected as lifetime points. Generally it has been inquired as to how many years pass before respectively 25, 50, 75 and 90 percent of the marketed amount in a given year is scrapped. For practical reasons, lifetime data has only been collected for the products which account for more than 75 percent of the marketed amount within a product category. This lifetime data has been subsequently developed to be continuous lifetime profiles by the help of a Weibull function.

Calculation of the waste amount for EEE-products takes place by reducing the marketed amount for a given year in accordance with the constructed scrapping frequencies.

\subsection{The tool}

The Excel tool is developed in the project as a test and illustration of the method, but can also be used for actual calculations if data is available.

The tool is supplied with data of marketed amounts in Norway in the period 1986 up to and including 2007. The data includes 28 different products in categories 2, 3, 4, and 7 according to the WEEE directive's product category classifications. New products can be entered and existing products can be modified and saved. The tool further contains a set of lifetime profiles, which have been collected in 2008 and accordingly represent the estimate applying to the products being on the market today. The same lifetime profiles are used on the historical data, but the tool has the ability to use multiple lifetime profiles for different historical periods of the same product.

The calculation of the amount of WEEE which arises in Norway is only meant to illustrate the method's usefulness. The input data used for 
testing is not quality-assured and the calculation results consequently ought to be regarded as indicative.

\subsection{Results and discussion}

Despite limited quality assurance of the supply data used, the calculations show results that are rather consistent with other calculations and data sources. However, the results emphasize the necessity of making a qualified and thorough review of input data for the calculations.

The use of lifetime profiles in the calculations results in more reliable and dynamic waste calculations than would be the result with fixed average lifetimes. However, reliable lifetime profiles are not available for most products. To take full advantage of the method effort must be laid in obtaining lifetime profiles.

The results show a reasonably large degree of conformity with other calculations made in Norway. Thereby it can be concluded that the method and the tool have shown to be functional.

The tool is available electronically in an Excel format prepared in version 2007. A guidance has been prepared, which likewise is included in the tool.

It must be underlined that the project joint venture (Mepex $\mathrm{A} / \mathrm{S}$ and Econet AS) disclaim responsibility for how a third party might use the tool and its results. The objective of the project has exclusively been to develop a method for calculation and data collected for the project is accordingly only used exemplarily. 


\section{Introduction and Methodology}

\subsection{Waste of electrical and electronic products}

The use of electric and electronic equipment (EEE) is steadily growing in our everyday life. Except from constituting huge quantities, these products also consist of hazardous and valuable materials which must be handled in a proper way to avoid pollution and waste of resources when being discarded. Consequently, many countries and international organizations have adopted regulations of collection and treatment of WEEE ${ }^{1}$, among them EU's WEEE directive ${ }^{2}$.

Reliable figures on the quantity of WEEE are crucial in order to evaluate compliance with regulations set by the authorities. Reliable figures are also important for monitoring and further improvement of return schemes.

In the present situation, there is still a need for more accurate information on the quantity of EEE put on the market as well as the quantity of WEEE generated and discarded each year. The situation is more or less the same in all countries making it difficult to compare and evaluate the results of ongoing initiatives.

At least two elements are influencing the amount of WEEE, and therefore necessary for calculating reliable statistics of WEEE:

1. Quantity of products put on the market.

2. Lifetime of the products.

The use of EEE products is constantly changing because of new requirements, technical improvements, consumer preferences, etc. This tendency makes it more necessary to have accurate statistics on the quantity of EEE put on the market. The quality and detailing level of the statistics are also quite different between countries today. Even though new producer registers are established in the individual countries, they will also have limitations regarding detailing level and scope (i.e. free riders are not registered).

Because of the dynamics in quantities and the composition of EEE products put on the market, the lifetime of products is crucial when estimating quantities of waste. There is a lack of methods and models ${ }^{3}$ to

\footnotetext{
${ }^{1}$ Waste Electrical and Electronic Equipment

${ }^{2}$ EC (2002). Directive 2002/96/EC of the European Parliament and of the Council of 27 January 2003 on waste electrical and electronic equipment (WEEE).

3 Please note that the notions model and method are used synonymously throughout the report.
} 
predict dynamic lifetime profiles for EEE. The existing estimate is normally based on simple assumptions regarding average lifetimes for products and product categories.

This project is established with the purpose of developing a first version method that can calculate the quantity of generated WEEE, so that in general this project should be considered as a research and developing project.

\subsection{The objective of the project}

The objective of the project is to develop a commonly agreed method according to defined requirements and tested on realistic data for selected EE products and product categories.

The possibility to combine information of supplies and lifetime profile of one defined product or a sub-group is important for the result. The detailing level must be adapted to the big difference in lifetime profiles between products in one product category. The method has to take into consideration the various detailing levels of supply data.

\subsubsection{The objective}

The overall objective of the present project is to develop a method producing national figures which can be based on different consumption patterns and lifetime profiles between countries.

The project also has an intermediate purpose in connection with the overall objective. This purpose is as follows:

Testing of the method with a set of input data based on common lifetime profiles for a Nordic country with reference to preferable products/product categories.

The above mentioned purpose is formulated serving a basis for the examination of the potential for a simple, handy method.

\subsubsection{Target groups}

The target groups are authorities, official statistical agencies, return schemes and consultants providing them with a tool to calculate the yearly quantities of WEEE that accumulate in a country. These calculations can give input for an evaluation of results and possible changes in systems and regulations. 


\subsubsection{Expected results}

- A recommended method that sets up the procedures of how to collect and organize data in order to estimate the quantities of electric and electronic waste (WEEE) in the future.

- A method applied to a demo-model illustrating the practical implementation of the calculations.

\subsection{The completion of the project}

The project has been completed in five work stages A-E (Figure 2.1), the most important results of which are shown in the current report.

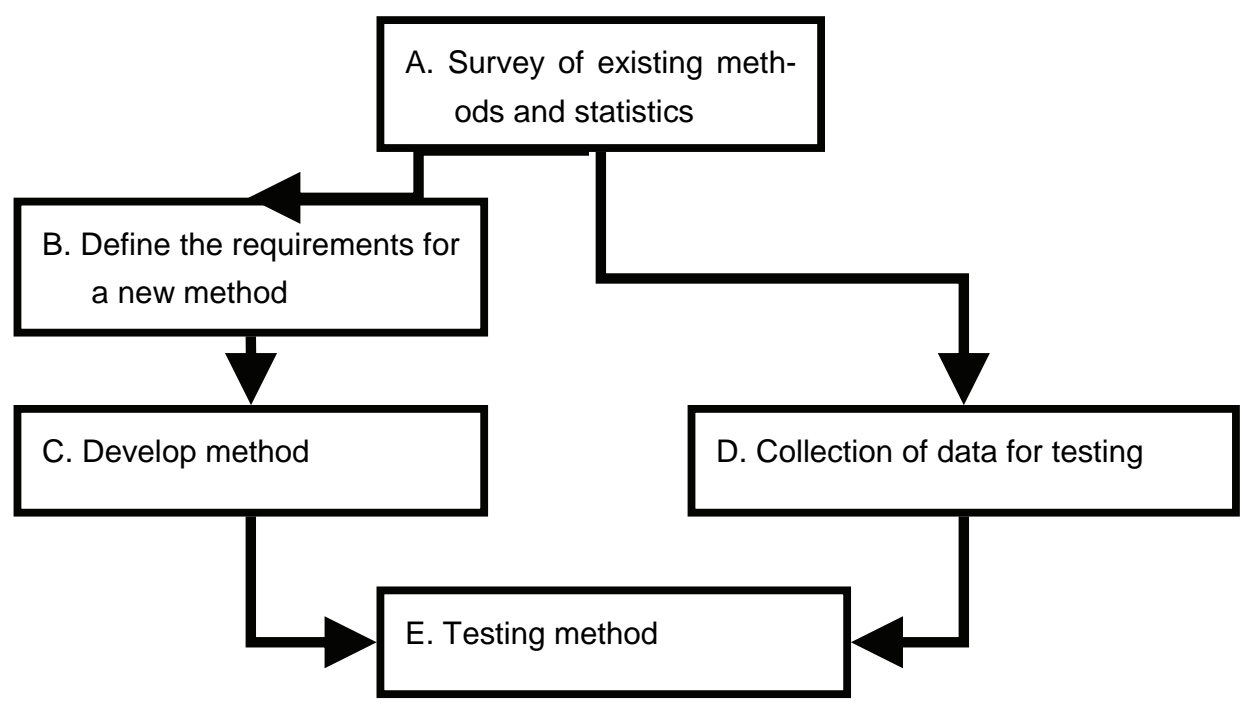

Figure 2.1. Project stages.

The first stage (A) included a review of existing statistics for consumption and collection of electric and electronic products. The purpose was to be able to take a comprehensive view over accessible data in this area. Furthermore, the work included a literature screening which could give knowledge and inspiration for an establishment of a usable method or model.

At stage B in the working process, requirements to the method were formulated. Some requirements had been specified ${ }^{4}$ in advance and others were formulated as guidelines as a result of the current discussion in the project regarding level of ambition and the project's possibilities for establishing a practical method. Originally it was not a requirement to develop a tool. However, during the course, the project found that such a tool was useful in order to illustrate the result of the project. In this con-

\footnotetext{
${ }^{4}$ Invitation for tender bids - A method to measure the amount of WEEE generated, Norwegian Pollution Control Authority, 14.9.2007
} 
nection a few general guidelines were established for the functioning of the tool.

Stage C included development of the method on the basis of the collected knowledge, which was generated in stage A and the guidelines, which were listed in stage B. At this stage, work was likewise done to adjust mathematical functions for estimation of continuing lifetime profiles on the basis of lifetime data in a worksheet. For this assignment external assistance was being used.

At stage $\mathrm{D}$ real data was being collected for the method. This concerns data for marketed electric and electronic products for a longer period until and including 2007, see Chapter 8 and Appendix 5 and 6. The length of a historical period of time was at the same time determined. Furthermore, an expert panel was established in order to contribute estimated lifetime data for further selected products, see Chapter 6 and Appendix 3. The total effort at this stage resulted in a set of operational data which could be included in the following method test.

Stage E included a test of the present method/tool. Two general questions were formulated, namely with regard to the method:

- Whether the method produces reliable/dependable results, in other words whether the method calculates correctly.

- Whether the method complies with the requirements and follows the guidelines, which have been formulated.

In that connection the method's calculations were being compared with parallel assessments from the return companies for the year 2007. The tool's functioning was likewise being tested through a number of trials. 


\section{Approaches}

\subsection{Consumption and lifetime}

The purpose of this project is to set up a method which is able to estimate the yearly quantity of electric and electronic waste (WEEE).There are especially two conditions which determine this waste quantity, namely the development in our consumption of these products and the development in the lifetime of the products.

\subsubsection{Consumption and waste quantity}

A given waste quantity is a consequence of consumption through a shorter or longer period. The waste quantity is typically a result of the product being worn-down or consumed. The natural lifetime of the product can also be expired, which means that the product is still able to function but has been replaced by a more up-to-date product. We can consider the progress as a flow of goods, which are being still more refined until they are being removed and end in the waste flow. This progress can also include sale of used products from the first consumer to a new consumer (re-use) until they also end as waste.

The development in the waste quantity is influenced by people's consumption which again is dependent upon their economic ability, and a connection has been ascertained between the economic ability in society and the waste development. Today this connection is being challenged where it is an objective to reduce the waste development totally, regardless of the development in the economic activity (decoupling). The pursuit of this aim includes among other things research and development in lighter and more durable products where components to a greater extent can be recycled when the product is later worn-out. This also implies that research in consumer behavior is being carried out, i.e. in the mechanisms which control and determine the shopping preferences of the consumer.

The development in the future waste quantity is consequently dependent upon several parameters, i.e. on the one side the development in the size of the population, in the economic activity, in the supply of products and on the other side of the technological drive in the development of lighter and more recyclable products and components.

To calculate the waste quantity therefore requires that one must relate to the expected development in the mentioned parameters and the historical development. Anyhow there will be a complicated calculation, which involves several unknown quantities and great uncertainty. 


\subsubsection{Lifetime}

A product has a natural lifetime defined by a combination of a product being worn and that there is no longer use for it, for instance when more attractive products are put on the market. A product's lifetime is of decisive importance for how the waste development is proceeding during time and consequently is of special importance when calculating the waste quantity. To this can be added that the authorities' intervention can have influence on the lifetime.

In the literature which has been studied in the present project, determination of lifetime has been discussed. It appears that very sporadic knowledge and data of lifetimes for EEE products exist. Only for larger and more frequently used products in the housekeeping (refrigerators, washing machines, etc.), more qualified and justified bets on the average lifetimes exist.

The lifetime of individual products is different for many reasons and depending on the individual product's life history, construction etc. Within a product type, the average lifetime is a rough and simple estimate, but it gives no information about the variation among the individual products. When marketed quantity is varying, the use of average lifetimes in the calculation can give serious errors. As an alternative, lifetime profiles will give more reliable calculations.

\subsection{Literature screening}

In connection with choice of method for estimating electric and electronic waste in the present project, a smaller literature screening has been carried out primarily in the Nordic literature. The purpose of the screening has been to examine whether there are simplified methods which can be implemented and used.

The literature screening uncovered a number of reports with focus on estimation of actual and future waste quantity generally, and specifically for a number of electrical and electronic products. The literature show different methodical accesses with special adoption to the field of subject which has been illustrated.

In the found literature the below mentioned items have been specially mentioned:

- Econometric Model

- Dynamic Material Flow analysis

Both of which are models to calculate the future waste quantity. The first mentioned model type is seen used in connection with estimation of the 
waste quantity generally ${ }^{5}$, where the other model is being used in connection with estimation of the quantity for specific electric and electronic products ${ }^{6}$.

\subsubsection{Econometric model}

The Danish Environmental Protection Agency uses a model (FRIDA) ${ }^{7}$ to project the waste quantity. The model projects the expectation to the development in the quantity of waste by linking up the historical development in waste quantity with projection of the economical growth and projection of the energy production. For large waste flows, the connection between the economic development and the development in the quantity of waste is determined by an economic analysis in a given period. This involves that the quantity of waste changes if the economic activity changes. Consequently, an analysis has been carried out where the connection between the development in the waste quantity and the economic activity in society has been determined. In the econometric model, it is being tested whether the waste quantity per economic activity is constant over time or other circumstances should be included which can explain the constant development. Economic activity, the development in the population and also time are parameters which are used to explain the development in the waste quantity. A similar analysis has been carried out by Statistical Central Bureau in Norway ${ }^{8}$.

\subsubsection{Dynamic Material Flow Analysis}

The concept covers the understanding that knowledge about accumulation of a product is an important piece of information about resources and energy consumption as well as generating of waste and issues. MFA (the material flow analysis) draws up only the calculation of input and output at a given time. The dynamic material flow analysis estimates material flows for each period and consequently sets up a calculation of flows and supplies over a given period of time. On the basis of the historical supply,

\footnotetext{
${ }^{5}$ ETC/RWM (2005). Outlook for waste and material flows - Baseline and alternative scenarios, ETC/RWM working paper 2005/1

${ }^{6}$ Soline Van Wymeersch (2007). Dynamic material flow analysis of selected components and hazardous substances in televisions. Master's thesis Trondheim, June 2007

Bjørn Magnus Iversen (2007). Dynamic material stocks and flows analysis of refrigerant appliances in the Norwegian Waste Electrical and Electronic Equipment (WEEE) system. Master's thesis Trondheim, Juni 2007.

${ }^{7}$ Danish Environmental Protection Agency (2006) A model for projection of ISAG Data, FRIDA (En Model til Fremskrivning af Isag Data, FRIDA), Frits Møller Andersen og Helge V. Larsen, Arbejdsrapport nr. 35, Danish Environmental Protection Agency 2006.

${ }^{8}$ Statistic Norway (1999). Projection of waste amounts and environmental impact connected to final waste treatment (Framskrivning av avfallsmengder og miljøbelastninger knyttet til sluttbehandling av avfall). Rapporter (RAPP 1999/32)

Statistic Norway (2004). Projection of organic waste 2001-2020 (Framskrivninger av organisk avfall for 2001-2020). Notater 2004/38
} 
the model will project the future demand and waste development. The dynamic in the project is added by incorporating the population development and life style attitudes, which are central driving forces for the combination and size of the consumption.

During recent years in Norway, Dynamic Material Flow Analysis has been carried out on for example refrigerators and freezer lockers ${ }^{6}$ together with a selection of components and environmentally unsound substances in televisions.

\subsubsection{UK Market Transformation Programme}

In the report Review of Directive 2002/96 ${ }^{9}$, a description has been made of a tool "UK Market Transformation Programme (MTP)", which uses a complex iterative approach for calculating the future effect of individual products. The tool requires detailed knowledge of a product's sales history (stock, sale, utilization and resource consumption). This knowledge has been collected for a couple of specific selected products as for instance televisions, freezers and electric motors. The report concludes that it will take a long time before a year to year data base has been established with the necessary market information for all relevant products, and it will require a substantial resource effort to obtain the necessary data. The report further concludes that in lack of operational models, the quantity of future WEEE will be projected by linking the actual quantity WEEE with the domestic product and population data. In principle this corresponds to an econometric model consideration.

\subsubsection{Armed epoxy and polyester plastic projections}

In 2001 the Danish Environmental Protection Agency implemented a project aiming at establishing a view of the consumption and composition of armed epoxy and polyester plastic (composite materials) in Denmark $^{10}$. In this connection it was estimated how large quantities of composite waste could be expected during the coming 20 years. Products which contain epoxy and polyester plastic, for instance windmills and boats of glass fibers have a very long lifetime. On the basis of information of the consumption of armed epoxy and polyester plastic in Denmark during the past 35 years and the expected lifetime of the products, projections were made for waste quantities for the period until 2020. The lifetime has been determined based on a guaranteed minimum lifetime and knowledge of how big a part of the product (for instance a windmill) has

\footnotetext{
${ }^{9}$ United Nations University (2007) 2008 Review of Directive 2002/96 on Waste Electrical and Electronic Equipment (WEEE). Final Report.

${ }^{10}$ Danish Environmental Protection Agency (2002) Armed epoxy and polyethen plastics - consumption and waste amounts (Armeret epoxy og polyesterplast, prognoser). Miljøprojekt 656, 2002
} 
passed this minimum lifetime, but at the same time has been removed from operation. It is a question of a rather simple projection method.

\subsubsection{EEE waste quantities in Norway}

In a report from the Environmental Agency in Norway ${ }^{11}$, a waste quantity is estimated at a given point of time (1998) on the background of historical data, which is based on information about foreign trade and production. The report does not include data for future waste quantities as the purpose has been to compare the waste quantity for 1998 with an earlier assessment. Consequently this is a matter of a specified time limitation. The model can easily project the waste quantities for a longer period in the future on the basis of built-in lifetimes. In the assessment, an average lifetime has been estimated for each product.

In the report, it is indicated that the lifetime is influenced by several circumstances and that the lifetime varies considerably within each individual product type (item number in the public statistics), but that the used average lifetimes are quality assured by the electronic business branch.

The estimates for waste have later been updated in the spring of 2003 by the electronic business branch for the return company RENAS ${ }^{12}$.

\subsection{Conclusion and choice of method}

It appears from the above that several methods exist which can be adjusted to the issue in the current project. The choice depends to a great extent on which and how many resources, which are available for maintenance and operation of the method, which has been chosen. The methods, which are more dynamic and sophisticated, require more types of input data and thorough knowledge about the correlation in connection with the waste quantity which is being estimated. This knowledge does not exist and will require a great resource effort to procure. Consequently these methods can as far as it can be estimated today only be seen utilized on a relatively limited number of products. The methods are best suited for larger homogeneous waste flows and are less suited for product categories facing large technological development, which is the focus in this project.

On the contrary, do the more simplified flows require fewer input data, which makes it easier to use them, but at the same time the dynamic element is lost due to the fact that the number of products, which are put on the market in the future, are based on a straight-line projection of the

\footnotetext{
${ }^{11}$ Department of Environment, Norway 1998. Electric and electronic waste (Elektrisk og elektronisk avfall). Hjellnes Cowi AS, February 2008.

${ }^{12}$ Renas AS (2003) Waste estimates of EEE products within the responsibility of RENAS AS (EE-avfallsanslag innenfor Renas sitt ansvarsområde). Hjellnes COWI AS, Oktober 2003.
} 
goods supply within relatively few years. In other words, a more detailed specification is obtained when losing the dynamic. The mentioned literature shows, however, that the simplified methods can handle a comprehensive number of products, because it is relatively easy to collect the type of data which is necessary ${ }^{13}$.

Seen in the light of the project's issue, it stands to reason to start with a more simplified method, which contains few input parameters.

Such a choice will in no way eliminate that at a later point of time one or more dynamic elements can be linked to the method. In this connection it could be considered if such a dynamic linkage ought to include all products or only the products, which will result in large waste quantities or the products, which are considered to give the greatest challenges in anticipation of reducing the environmental strain.

${ }^{13}$ In the report referred to in footnote 12, the approach includes 572 commodities (commodity positions) out of a total of 891 commodity positions covered by the WEEE-directive in 2003. 


\section{Requirements}

\subsection{The Method}

It is stated ${ }^{14}$ that the method to be developed must meet the requirements listed below:

1. The method must be able to estimate/measure the quantity of WEEE generated annually in a country,

2. The method must be flexible in order to adjust to shifts in trends of consumption,

3. It should be possible for others (e.g. consultants or authorities) to use the method and to adapt when new calculations later need to be made,

4. Other member states than the Nordic countries should be allowed to use the method.

The requirements have been directive for the work of the project with regard to choice of method and development of tools.

No specific target group has been defined, though it is mentioned ${ }^{1}$ that it should be possible for consultants and authorities to use the method.

As it will appear later, the project has seen it as part of the assignment to illustrate how the method can be operated into a method or a practical tool (calculator). Consequently, the project has tried to think all stages in utilization of the tool (from data collection to implementation) into a whole.

As the user groups mentioned as examples (e.g. consultants or authorities) are presumed to represent different user conditions, the project has chosen to define authorities as the primary target group. Authorities should here be understood as environmental authorities in the Nordic countries, which have law preparatory as well as planning and monitoring assignments as fields of activity.

Clarification of the target group means that the decisions/solutions made during the course of the development work are decided from situation to situation based upon an evaluation of how the tool can be used simply with a minimum of resources in the administration.

The project has furthermore formulated a number of relevant instructions which lie in a natural extension of the above mentioned requirements. These are: transparency, reiteration, enlargement and simplicity.

\footnotetext{
${ }^{14}$ Invitation for tender bids - a method to measure the amount of WEEE generated, Norwegian Pollution Control Authority, 14.09.2007
} 


\subsubsection{Transparency}

The method should be transparent. It is important that the formulas comprised by the method are recognizable, understandable and based on objective criteria. It should appear which simplified assumptions it is necessary to make in the development of the method. This will ensure identical interpretations of the achieved results.

\subsubsection{Reiteration/enlargements}

The method should lead to a model being easy to use and ensuring the same results regardless of users and repetitive trials.

The method will be developed so that changes in the presumptions and data input can be made meaning that:

A new product and related lifetime profile can be added.

The lifetime profile can be adjusted in accordance with the introduction of a new product replacing an existing one.

Changes can be made in reported quantity collected, generated WEEE.

\subsubsection{Simplicity}

When constructing the tool, importance will be attached to simplicity and pedagogic explanations. By simplicity is also understood that the user without special technical qualifications can use the tool - high degree of usability. As the method will function in an EDP based tool (demo version), it will be necessary to describe the functions of the tool. The description can be found in a separate brief guidance.

\subsection{The tool as a calculator}

It has been the purpose of the project to develop a method which is able to make the required estimates. However, it is appropriate to illustrate the method's usability. Consequently, a tool has been made in a demo version with the most basic facilities. The demo version forms a good basis in order to be able to evaluate whether it will be necessary later to develop a fully completed tool, which can handle all the electric and electronic products comprised by the WEEE directive.

If such an extension is chosen, it will be necessary to phrase a more precise requirement specification. Such a requirement specification has not been a topic in the current project. Besides a stipulation of target group and user level, the specification ought to include a clarification of the facilities of the tool. It should among other things be considered how the tool can be developed with a data input module and also how conditions as estimates of different scenarios can be saved and compared with the tool's own data input. 


\section{Establishment of a method}

\subsection{Data}

Utilization of a method includes an establishment of a tool, which can carry out the necessary calculations. On the basis of the completed literature screening, it has been decided to develop a method based on:

- Data for the marketed electric and electronic products (data input).

- Estimated/anticipated lifetime allocations on product type level.

The extent of data parameters for the method is hereby brought down to a minimum. This is of importance for the resources which should be put at disposal in connection with data collection when the method has been implemented.

\subsubsection{Marketed quantity}

Marketed quantity (data input) is defined here as the quantity of a product, which has been/is being introduced on the market each year. Several sources exist for obtaining data input. In this project it has been decided to use data from Statistics Norway. The reason for this choice is pure pragmatic. The project has excellent contacts to the bureau thereby facilitating the work with defining and establishing the necessary data input. In Chapter 8 further details are mentioned.

\subsubsection{Lifetime}

Lifetime is defined in this project as the time a product is on the market (in the household) until it ends in the waste flow or in a return collection system. The problem with using lifetime in this connection is, however, (as previously mentioned in Chapter 3) that it is not known. A survival profile does not exist for a product, which based on experience and measurements can illustrate how a product is gradually phased out to the waste flow over time. Consequently, the method must be based on assumptions or experience data. In two reports (Armed epoxy, 2002 ${ }^{10}$ and Renas, $2003^{12}$ ) adjusted average lifetimes based on branch information are used. Lifetimes in the two projects are used with a different degree of perfection. In Chapter 7 the calculation method for the lifetime profile has been described.

In this project lifetimes have been collected by approaching manufacturers/dealers in the branch for electric and electronic products and also 
from collectors and processors of discarded similar products. For collection and determination of lifetimes, a semi scientific method has been used, namely the Delphi method. In Chapter 6 the method has been further described.

\subsection{The structure of the method}

In figure 5.1 it is shown how the method has been designed, comprising which data is included and also which operations are carried through in the individual steps during the calculation process. The method illustrates the process which is being used in connection with the present project and will be identical with the routine, which is established when the method has been fully implemented. In the following the method is being shortly described with reference to a more detailed in the following chapters.

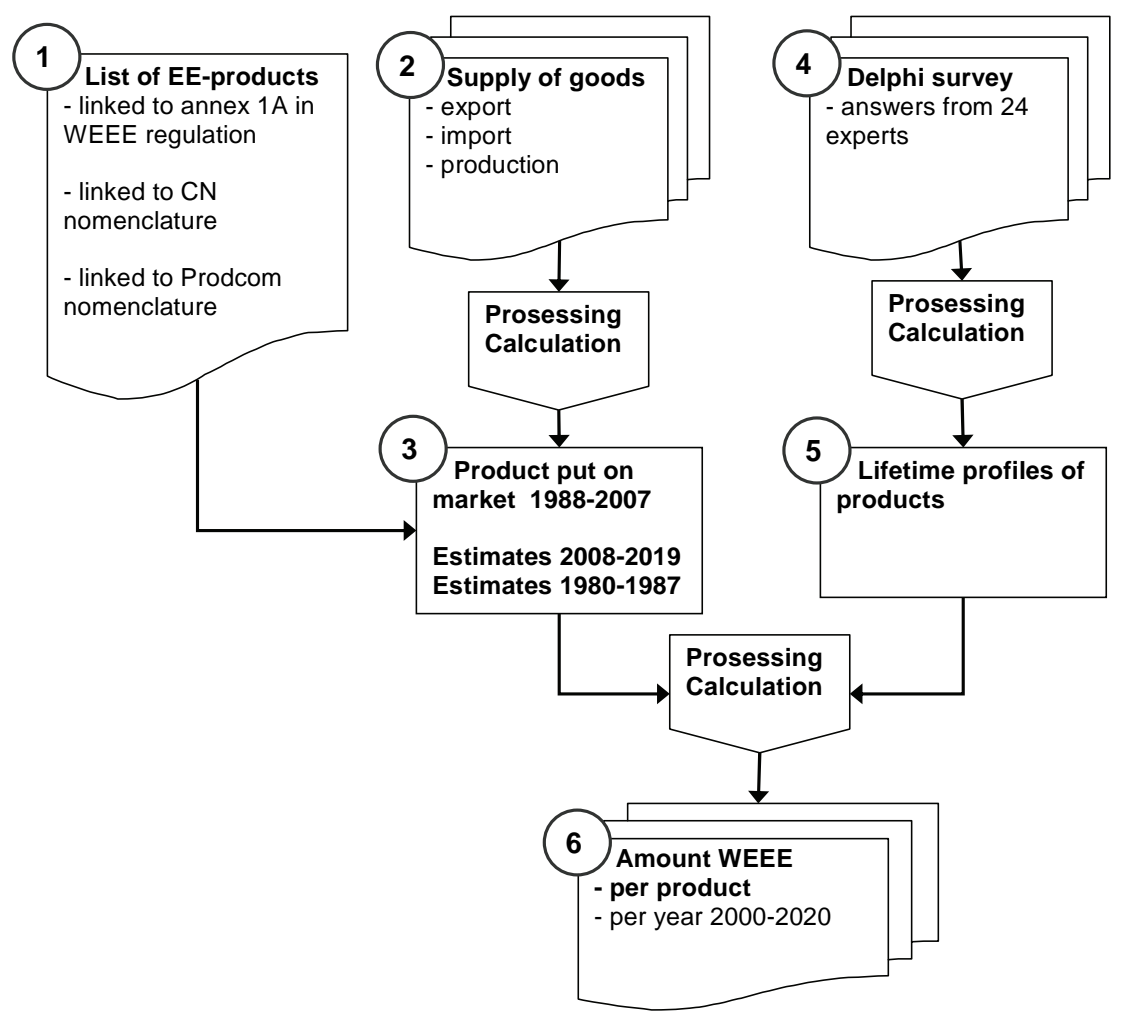

Figure 5.1 The structure of the method

\subsubsection{List of EEE products - Step 1}

The data population is defined based on the Directive's Appendix 1A and $1 \mathrm{~B}^{2}$. A product in the foreign trade statistics is, however, classified ac- 
cording to a $\mathrm{HS}^{15}$ classification and in the production statistics according to a Prodcom ${ }^{16}$ classification. Consequently, a linkage table must be established which shows which product positions are EEE products and which product category they belong to. The product categories in the WEEE directive's Appendix 1A are too compound, and these must be divided into product types corresponding to Appendix 1B. A so-called linkage table has been made for the product categories 2, 3, 4 and 7 . Some countries have established an EEE register where each product type has a direct reference to a product position number in the national statistics. In this case, it will be the products included in the register, which are used to define the data output from the National Statistics Bureau.

\subsubsection{Supply of goods - Step 2}

Data is being prepared and collected here for yearly import, export and domestic production disclosed in weight. The population is being delimited, as only positions which contain electrical and electronic products are included, confer Step 1. The information is obtained from the National Statistics Bureau. The same information is also available at the individual return companies (which must themselves calculate a collection potential). The return companies can, however, consider such information as confidential due to competition considerations ${ }^{17}$ and the data can be limited to the member mass of the companies. Information from nonmembers (free-riders) is not included in the data of the return companies.

\subsubsection{Products put on the market - Step 3}

Preliminary data covering yearly import, export and domestic production (Step 2) is categorized in accordance with the dividing of the products (Step 1). Yearly input is being calculated according to the formula: "import less export plus production”. The result of the linking of defined EEE-products and the national product and foreign trade statistics is a specification of the quantity of EEE-product types which have been marketed for the year in question.

For natural reasons, it is only possible to assess a marketed quantity for the most recent (made public) years. In order to be able to estimate future waste quantities, it is also necessary to know future input of products. It will be necessary to extend the data base of the method with estimates for products put on the market in the future. Future input of prod-

\footnotetext{
${ }^{15}$ Harmonized System (HS) is the nomenclature of FN's statistics of import and export of commodities, see section 9.4.1

${ }^{16}$ Prodcom is the nomenclature of EU's statistics of production of commodities see section 9.4.2

17 This applies mainly in countries where there are established more than one returning company performing the collection of waste electrical and electronic equipment (WEEE) in accordance with the directive.
} 
ucts has in the project been calculated based on the individual estimates through extra polishing, however, corrected based on a qualified estimate.

\subsubsection{Lifetime data - Step 4}

The other important data input for the method is lifetime data for the product types. In the present project, lifetime data has been collected for the chosen product types via a Delphi panel. Only current lifetime data has been collected. Many products produced $10-15$ years ago were designed and assembled very differently compared to today. Particular design, size, user functionality and consumer behavior have changed character through the years, which means that today the products are more fragile and vulnerable against external effects. The chosen approach in the project is debatable but a pragmatic choice. It involves that the product types marketed in for instance 1999 are equipped with a profile which could very well be different from the profile set for the product if the lifetime had been estimated in 1999. The procedure and the results have been described in Chapter 6. Lifetime data for specific product types has been collected. The procedure has been that lifetime data has been collected for the product types, which within each product category (2, 3, 4 and 7) together accounted for more than 75 percent of the product category's total tonnage.

\subsubsection{Lifetime profiles - Step 5}

On the basis of the Delphi panel's five data points for each product, a continuous (yearly) lifetime profile has been estimated. Furthermore, an average lifetime for the selected product types together within each product category is being estimated. The average lifetime is used on the remaining 25 percent of the product category's quantity for which no lifetime data has been collected. A Weibull distribution is used to transform life time data points to a lifetime profile, see Chapter 7.

\subsubsection{Amount WEEE per product - Step 6}

In this step, scrap profiles have been estimated for the product types. The specific yearly marketed quantities in the contemplated period have been distributed in accordance with their respective lifetime profiles. On the basis of this, a yearly scrap quantity for each product type can be estimated. The scrap quantity for each product type is added up, resulting in the scrap quantity (WEEE) for all selected product types assessed in tons per year. 


\subsection{The method as a tool}

The above method has been implemented in Excel as a demo-version. This means that the method is developed as a prototype in order to be tested on a number of further defined product types in the present project. In the establishment of the prototype, importance has not been attached to establish a high usability level (user interface). It has merely been the intention to secure that it will be possible to carry through the necessary estimations in a palpable way.

When the demo-version has demonstrated its usability, the next step will be to extend it to include all the electric and electronic product types which are comprised by the WEEE directive. Furthermore, it will be appropriate to develop the method in a more user-oriented application.

In the connection with the current demo-version, a help manual has been made. The manual describes shortly the assumptions which the method is built upon. Furthermore, the manual describes the steps, which the user must read from collecting and processing of data until results from the calculation are available. 



\section{Collection of lifetimes}

\subsection{Choice of method}

The Delphi method has been used in this project for collection of lifetimes. The method is primarily used in connection with future studies but can also be used in connection with phenomena, which are difficult to measure today or in situations where there are several variables. The method has previously mostly been used to estimate quantitative variables; however, today the method is being used in several areas - society scientific as well as nature scientific conditions.

Compared to electrical and electronic products, other methods exist to collect information about lifetimes. Selected analyses made on processing plants, where electrical and electronic products are being counted, are being identified and decoded compared to production year and can form a basis for stipulating factual lifetimes. The method is, however, both resource and cost requiring and at the same time slow.

If the method is used as a part of a larger selective analysis, it could naturally be contemplated possibly as a supplement for other collection methods.

Collection of information from manufacturers will be a toilsome piece of work, especially because it is necessary to involve many manufacturers. There is no doubt, however, that many bigger enterprises within the branch could be in possession of relevant information. Concurrently with that, primarily the bigger manufacturers experience the effect of the WEEE directive, new reporting systems are being established where the flow of the product is followed until the product is phased out. The observation of such product flows can give suitable data about lifetimes.

On basis of the above mentioned, the Delphi method is regarded as a simple method, which is easy explain.

\subsubsection{The Delphi method}

The principle in the Delphi method is that an approach is made to a group of experts (a Delphi panel). The approach results in a number of replies, which the project processes. The project can choose to continue to ask or choose to present the received replies for all the respondents (anonymously) with the objective of giving the respondents a possibility to reconsider their first answer. This procedure can continue until the project can go no further. It is recommended that $2-4$ inquiry rounds are taking place. At least 2 inquiry rounds are recommended. 
There are no fixed criteria for how to complete a Delphi analysis. The following procedures could be recommended: ${ }^{18}$

A monitoring team is established which reads itself in on the subject, selects members, works out problem formulating and questionnaire and also makes the finishing treatment.

A Delphi panel is being established. The members can have the same background, i.e. see the problem from the same starting point, however, this is not a requirement. The members in the panel ought not to know who the other members are and consequently will never learn (by mentioning of names) how the individual members reply.

The method is aiming at the members always giving subjective replies. If this was not the case, the objective reply would be found, wherefore it would not be necessary to carry out a Delphi analysis.

The number of members in the panel should be considered. It is seldom possible to obtain a statistical certainty because the members are selected based upon their knowledge and it is difficult to prove that the information quality increases proportionally with the number of answering individuals. It is often so that with an increased number of answering individuals, the possibility of doubtful knowledge occurs. In other sources it is being recommended that the panel has a great number of members - exactly because the answers are subjective. In a Swedish study 20 individuals were being asked. In other surveys a number of between 6 and 8 was found suitable.

\subsection{Collection of lifetime data}

In relation to this project, the Delphi method has been used to determine lifetimes. A Delphi panel was appointed. The selection of individuals has taken place by contacting the return companies Elretur and Eurovironment in Norway. In Denmark, EL-retur and RE-DK contributed. The return companies appointed a number of experts among their members to participate in the panel. Thus the panel consisted of manufacturers, wholesalers and experts from waste management facilities.

Participants had not information about each other's identity. Totally 13 Norwegian and 11 Danish individuals were included, or a total of 24 individuals representing persons within the distributor and collection element.

\footnotetext{
${ }^{18}$ The Swedish Dairy Industry (2005) 2010 - A Delphi Study (Den svenska mejeribranschen år 2010 - En delfi studie). Frederik von Unge, Department of Business Studies, Uppsala 2005
} 


\subsubsection{Formulation of the questionnaire}

The degree of response to a questionnaire depends on several things. The number of questions is naturally of importance and also the relevance for the responder. However, most important is the time which the responder chooses to use on the replies. Ideally the project wished to have the experts' view on the following circumstances:

- How long is the technical lifetime for a product?

- How long is the technological lifetime estimated to be for the same product?

- Will the product in question have a second life before it ends in the waste flow and if so how long will that be?

For each product a number of points in the lifetime profile should be determined, (see Chapter 7).

A test of a questionnaire containing the above mentioned three questions for each product showed that it was difficult for the respondent to handle the different lifetime concepts.

Consequently, the practical solution was to ask how long the respondent thinks that the product will be on the market (is in the household) before it can be found again in the waste flow, i.e. either in a return system or in another waste system. In this way it will only be the individual respondent, who intuitively should include the different lifetime concepts in his answer.

The questionnaire was designed in an excel file and forwarded via mail with an attached covering letter.

Covering letter and questionnaire can be seen in Appendix 1 and 2.

\subsubsection{Results of the survey}

The survey was carried out in two loops in accordance with the basic methodical idea in a Delphi survey. In the first loop the experts' first evaluation of lifetime points for the selected products was being collected.

The received results were being data processed and an average lifetime for each lifetime point was being calculated.

In the other loop, the experts in the Delphi panel were being presented with the average lifetime points in a spreadsheet. At the same time the respondent's own suitable replies were included in the table so that the expert could evaluate his own replies compared to the panel's total replies.

The purpose of the other round was exactly to give the individual respondent the possibility to revaluate his first given reply based on a more "qualified" basis for decision. In Table 6.1 the panel's replies are presented. 
Table 6.1 Results from Delphi panel

\begin{tabular}{llrrr}
\hline & Delphi panel & Norway & Denmark & Total \\
\hline \multirow{2}{*}{ 1. loop } & No. of experts & 13 & 11 & 24 \\
& No. of answers & 9 & 10 & 19 \\
& & & & \\
\multirow{2}{*}{ 2. loop } & No. of experts & 8 & 10 & 18 \\
& No. of answers & 6 & 9 & 15 \\
& - of this with changes & 2 & 1 & 3 \\
\hline
\end{tabular}

In the first loop, 19 out of 24 experts responded corresponding to a response of 80 percent. In the second loop 18 experts were questioned again and 15 experts responded. Out of these 3 experts had made changes. Many of those who did not make changes remarked that they maintained their first answers even though some of these answers varied significantly compared to the average lifetime implemented by the group. The lifetime calculations were revised according to the final changes of the experts. An example of the results is shown in Table 6.2.

Naturally, nobody can say with certainty whether the calculated lifetimes are realistic. The calculated lifetimes should be seen as an expression for "best choice". If you regard the differences in lifetimes for the different types of products, a certain mutual consistency seems to exist. Products, which in a traditional sense are considered as long lasting consumer goods, are also estimated by the Delphi panel as having a longer average lifetime than other products, which for instance run through a quicker technological development and for that reason results in a shorter lifetime.

Table 6.2 Lifetime estimates for selected products

$\% \quad$ Number of years

\begin{tabular}{|c|c|c|c|c|c|}
\hline Products on sections & $<1$ y & $25 \%$ & $50 \%$ & $75 \%$ & $90 \%$ \\
\hline \multicolumn{6}{|l|}{ Small household appliances (Section 2) } \\
\hline - Sewing machine & 2 & 5 & 8 & 11 & 15 \\
\hline - Hair dryer etc & 9 & 2 & 4 & 6 & 7 \\
\hline \multicolumn{6}{|l|}{ IT- and tele communication equipment (Section 3) } \\
\hline - Telephone & 5 & 3 & 5 & 7 & 9 \\
\hline - Electronic calculators & 7 & 3 & 5 & 6 & 8 \\
\hline \multicolumn{6}{|l|}{ Consumer equipment (Section 4) } \\
\hline - Radio, loudspeaker & 4 & 4 & 6 & 8 & 10 \\
\hline - Portable MP3 & 5 & 2 & 3 & 4 & 5 \\
\hline \multicolumn{6}{|l|}{ Toys, leisure and sports equipment (Section 7) } \\
\hline - Electric trains, including rails and other equipment & 3 & 5 & 7 & 10 & 13 \\
\hline - Other electric toys with engines, made of plastic & 9 & 2 & 3 & 5 & 6 \\
\hline
\end{tabular}

Legend: Column 2 " $<1$ year "meaning that $X$ percent of the marketed product will end up as waste during the first year. Column 3 "Number of years" meaning that 25 percent of the marketed product will end up as waste within 5 years (sewing machine and electric trains). Consequently, the column 4 (50 percent) expresses the average lifetime of a given product.

The lifetime distributions are calculated as a simple average. Each Delphi response (lifetime point) for one specific product is added up and divided 
with the number of respondents and hereby appears an average value for each individual lifetime point.

\subsection{The Delphi method as a tool}

In this project the Delphi method is only used as a pragmatic simple way to procure lifetime data with the objective to make the calculations as realistic as possible.

The suitability of the method has, however, not been compared to whether more loops and consequent expert evaluations would have given another result than the two loops which have been tested in this project. The procedure, however, deviates at one point compared to the recommended, as the individual expert (besides from his own answers) has only been presented with a mutual expression based on an average of the other experts' answers. A basic idea has otherwise been that each respondent gets the opportunity to see the answers from each individual respondent.

Regardless of these deviations from the method's basic concept, it is the project's evaluation that the Delphi method is useful for collecting data concerning lifetimes.

If the communication between the project and lifetimes is mail based and for instance supplied with internet based software for questionnaire surveys, a good control and quick response times can be achieved. In case much lifetime data must be collected, the method is especially resource saving. 



\section{Calculation of lifetime profiles}

\subsection{Choice of lifetime points}

During the literature screening it has been registered that some projects use an average lifetime whereas there in other projects are more lifetime points. Ideally seen as many as possible lifetime points are desirable. The more points the better for the possibility of modeling a more dynamic and continuous lifetime profile. In practice it is, however, completely impossible to inquire about all years in a lifetime of $20-30$ years.

In connection with collection of lifetimes in the current project, it was contemplated how many lifetime points it could realistically be expected that people reasonably could overlook. Lifetime points are collected via a Delphi panel consisting of experts (see Chapter 6). It must be assumed that these individuals regardless of their motivation will use limited resources for estimating lifetime points. It has been chosen to inquire about a total of five lifetimes. With five lifetime points a more dynamic profile is obtained in contrary to profiles, which are based on an average lifetime or on two or three points. Likewise it is considered realistic that the experts will be able to reply "realistically" to five lifetime points.

Many short lasting consumer products are worn out and discarded after a relatively short time. This can be due to defects and deficiencies or it could be a question of products, which either due to quick technological changes or change in trends are being replaced quickly by the consumer. Consequently, it has been chosen to inquire as to how large a part of a marketed quantity ends as waste already within the first year of living. Furthermore, the number of years have been assessed before 25 percent, 50 percent, 75 percent and 90 percent respectively are discarded. The used lifetime points consequently look as follows:

- $\quad<1$ year is defined as the part of a marketed quantity, which is discarded within the first year of living.

- The 0.25 -quantile is the age at which the first 25 percent of the products is being discarded.

- The 0.50-quantile is what is being considered as the typical lifetime for the products.

- The 0.75 -quantile is the age at which 75 percent of the products are being discarded.

- The 0.90 -quantile is the age where 10 percent of the products are still on the market. 
These lifetime points form the basis for establishing a lifetime distribution of a product. The procedure of collection of lifetimes in this project has been described in Chapter 6 .

\subsection{Distribution function - Weibull}

The absence of complete lifetime data results in the fact that a mathematical distribution function must be used in order to establish coherent lifetime distributions. For this purpose Weibull distributions ${ }^{19}$ is used as a method for the lifetime distributions. The Weibull distribution is widely used in reliability and life data analyses due to its versatility. Depending upon the values of the parameters, the Weibull distribution can be used to model variety of life behaviors ${ }^{20}$. Another advantage is the simplicity of the function.

Under certain circumstances the Weibull distribution looks like a normal distribution. The Weibull distribution has, however, the characteristic that it is asymmetric with regard to the average value and this implies the possibility that the lifetime can be "drawn out" for products, which have a considerably longer lifetime than the typical lifetime.

The data basis for the modeling thus consists of estimates of points on the survival distribution itself. This is in contrast to the more normal situation where observed lifetimes of a population form the data basis. As a result, the approach in this modeling will be different.

It has been assessed that for some product categories, there may be an increased risk of defects/scrap shortly after purchase. In this case, the Weibull distribution may not be sufficiently flexible to model the data. It was therefore decided to use method with a compound distribution: An increased risk for defects shortly after purchase, described by a parameter $k_{o}{ }^{\prime}$, and otherwise a Weibull distribution.

The procedure by using the compound distribution has been described in more detail in Appendix 4.

\footnotetext{
${ }^{19}$ http://en.wikipedia.org/wiki/Delphi_method

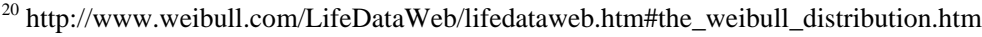




\section{Collection and compiling of data on supply of EEE-products}

\subsection{Choice of products for test calculations}

This chapter deals with selecting products for test calculations and the procedure, which is being used to establish the requested withdrawals from the official statistics. It is stated that four product categories should be chosen for the test calculations ${ }^{4}$ :

- Category 2. Small household appliances

- Category 3. IT and telecommunications equipment

- Category 4. Consumer equipment

- Category 7. Toys, leisure and sports equipment

(Category number according to Annex $1 \mathrm{~A}$ in WEEE directive, 2002/96/EC).

These broad product categories consist of a number of products, which have different characteristics and lifetimes. Consequently, it can be difficult to estimate the waste amount at this level. Because it is also of interest to study waste amount at a detailed level, the project decided to make calculations for detailed products in each of the selected product categories. However, there is no established classification of EEEproducts. Annex 1B in the Directive ${ }^{2}$ is a list of products in each product category, but this is not thorough.

The project decided to use official statistics as basis for the calculations; hence a connection to the nomenclatures of the official statistics is needed (statistical nomenclatures is described in 9.4). The project has accordingly found it necessary to establish a product list with links both to annex $1 \mathrm{~A}$ in the Directive and to the official nomenclatures of commodities (CN and Prodcom).

The nomenclatures of commodities in the official statistics have basically not been defined with regards to whether the commodities are EEEproducts. The CN-classification consists of 7.000 product positions and Prodcom of almost 4.600 positions. If deleted positions are included, but are still currently back in the lifetime of the products, the amount of product positions is even larger. Even though EEE-products are mainly found in limited parts of the classifications, it is a great task to draw out all product positions, which are EEE-products. Fortunately the Norwegian authorities have made a list of commodities in the HS nomenclature, which are EEE-products. The list is subdivided according to the product 
categories in annex 1A, but it has no functional product subdivision. The project has evaluated all the positions (commodities) in each category according to similarity and amount supplied to the market. The resulting list of products accounts for 75 percent of the amount supplied to the market. These products have formed the basis for collection of lifetimes (see Chapter 6) and calculation of supplied amount. The remaining positions in each category have been combined under "Other", which in the calculations has been given average lifetime from the products in the category.

As the Norwegian list of EEE-products has no connection to the Prodcom nomenclature, the project had to make made the connections with help of statistical correspondence tables ${ }^{22}$.

\subsection{Evaluation of simplified product categories}

The objective of the project is to develop a method, which can be used by all Nordic countries and countries in the EU. Accordingly, it is desirable to use a CN-classification at a 6 digit level, and consequently avoid use of the two last national digits. Another, but secondary advantage by using a 6 digit product number is that there will be fewer product numbers to deal with.

In the project, different tests and evaluations have been made as to whether a 6 digit product code is reasonable to use. The conclusion is that 6 digit product codes are in most cases homogenous, as they only consist of products, which are EEE-products of the same product type. However, some differences can exist between countries depending upon differences in the product combination. The conclusion is that a 6 digit product categories can be used if a requirement for the results at a detailed product level is not necessary.

\subsection{Time series and missing data}

As the products lifetime can be considerable, it is necessary to have input data back in time equivalent to the maximum lifetime of the products. In cases where maximum lifetime is extremely high ( $>20$ years) it could be a solution to limit the input data equivalent to the year where for instance 90 percent of the products have turned into waste. Alternatively, the input dating still further back can be calculated. Even though this is not quite correct, it will not affect the calculation result very much as the oldest products represent a small part of the generated waste.

Correspondingly, it is necessary to project the amount of EEEproducts put on the market if future waste amounts should be calculated 
by simple projecting of alternatively more sophisticated ways of forecasting.

Data back to 1988 has been accessible in the project. In order to calculate the historical waste amount which generates in the years 2000 to 2006 with up to 20 years of lifetime, input amount back to 1980 would have been desirable. The quantities in the period of time 1980 to 1987 are, however, immaterial for the waste amounts in the years 2000 to 2007. The quantities for the years 1980 until 1987 are consequently set equivalent with the amount for 1988 for each individual product.

Projecting of amounts of EEE-products in the period 2008 to 2020 has been made in Excel with the function "Forecast" corrected in such a way that the total increase in the input has been stipulated to 10 percent total increase in the period 2008 to 2018. However, it must be stressed that this only applies to the test calculations. No qualified evaluation has been made in the project of the future amount of EE-products to be put on the market.

\subsection{Compiling of data - step by step}

The compiling of data covering supply of EEE-products has in the project been carried out with the following work operations, shortly summarized: EEE-products identified in the commodity for foreign trade $(\mathrm{CN})$ using the Norwegian table ${ }^{21}$. The table is only normative and independent evaluations are recommended.

The identified commodities are connected to a product category in the WEEE directive's Annex $1 \mathrm{~A}^{2}$ with help of the Norwegian list.

Simplified supply of EEE-products (import - export) is being calculated for all identified commodity positions.

The identified commodities are combined to defined products based on an evaluation of similarity in function and type. The greatest importance is attached to those with the largest amount of so that defined products amount to at least 75 percent of the total amount within each product category. The remaining product positions are gathered in a category "Other".

For all products, a product number (x-yz) is established as $\mathrm{x}$ is category number in Annex 1a and yz is a serial number. Total for the category shows $\mathrm{yz}=00$ while the residual product category "Other" shows yz $=01$.

EEE-products are identified in the product classification for production (Prodcom) using a correspondence table $\mathrm{e}^{22}$ and independent evaluations. These are connected to the established product numbers

\footnotetext{
${ }^{21}$ http://www.ee-register.no/File/Vareliste\%20Web\%20130608.xls
} 
Total yearly product supply is calculated for each product number according to the formula: supply = import + production - export. It is all being put together in a table with products in rows and year in columns.

Supply of EEE-products in the period of time 1980 to 1987 are set equivalent with the amount for 1988 for each individual product, due to missing data.

Supply of EEE-products in the period 2008 to 2020 is projected with Excel function "Forecast" adjusted to a total increased amounts of 10 percent total increase in the period 2008 to 2018. However, it must be stressed that qualified projecting is necessary to obtain reliable calculation results for future waste amounts. 


\section{Evaluation of data sources on supply of EEE products}

\subsection{Considerations about data quality}

The reliability in the basic data is of decisive importance for the calculation result. However, the quality of the basic data is seldom fully satisfactory. It is therefore necessary to carry out a thorough assessment and possible correction of the basic data. The following sources of errors and assumptions should be evaluated together with the possibility of a correction:

EEE products It should be possible to select EEE-products from the non EEE-products.

Accessibility Should be accessible in electronic format. Data on desired detailing level should not be limited by confidentiality.

Errors in data Registration errors, mix up of items, mix up of products can occur.

Faults in data Faults, which are due to that companies or product types are not being included. This could for example bee free riders or product types, which are exempted from registration (military equipment).

Item Unit must be weight. Several data sources only have value or number.

Gross/net Packaging could represent a considerable part of the weight.

Time series It should be possible to find input data as far back as the length of the lifetime of the products.

Break in time series Change in classification, method of data collection, etc. can break the time series.

Product categories There must be consistency between lifetime data and the products, where calculations are desirable. There should also be possible to be aggregate data to the categories in Annex 1 in the WEEE directive.

Correction of inadequate data quality can be carried out in many ways and must be adjusted to the individual situation. It will often be natural to do this in connection with preparation of data and structures for use in the calculations. 


\subsection{Alternative data sources for EEE products put on the market.}

Alternative data sources on EEE products, which are put on the market, are available. It is recommended to make an independent estimate of which data sources can be found in the country in question and which are best suited for use in the estimates.

Two alternative data sources were evaluated in the project:

Product registers for WEEE, and official statistics.

The product registers, which are established as a result of the WEEE directive, receives data from the producers covering quantities. Such data, however, only exists from 2003 and in most other European countries. It is also a problem that the registers do not receive data from the producers who are not members in the return systems (free riders). Some product registers are also restrictive with distributing detailed data because of confidentiality.

The official statistical bureaus have detailed data covering import, export and production of goods. This data can be included in the calculations by using the formula: supply = import + national production - export. The statistical cooperation in the EU involves common classification, quality requirement and methods. The cooperation also involves the EØS countries Norway, Iceland and Lichtenstein. Despite that this data has an official status, it is necessary to evaluate the uncertainty and make necessary adjustments.

\subsection{Choice of data sources in the project.}

In the project, supply of EEE products has been calculated based on data from the Statistics Norway. Norway was chosen, because the project is well acquainted with data basis and previous works, which have been carried out in Norway. An evaluation of data sources in other Nordic countries shows that the data basis is the same and this also applies within the EU's member countries.

\subsection{Classification in official statistics}

Official statistics covering import, export and production are classified according to a very detailed nomenclature. It is decisive for the calculations to be able to identify the commodity positions, which are EEE products and assign them with the correct product type and category. 


\subsubsection{Import and export}

Statistics on import and export of products are in the European countries classified to the Combined Nomenclature (CN). This is to a large degree corresponding with the Harmonized System (HS), which is being used internationally.

The CN-classification consists of eight digits. The first six is common with the HS system, while the last two are national and can vary from country to country.

\subsection{Production}

Prodcom (Products of the European Community) is the nomenclature of EU's statistics of production of commodities. The code number consists of eight digits. The first four indicate the connection to EU's business grouping, NACE. The four last figures indicate the specific product.

As the only countries in Europe, Denmark and Sweden use the CN classification in their statistics on production (like for import and export). This will make it simpler to carry out estimates in these countries.

An official linkage schedule exists between $\mathrm{CN}$ and Prodcom prepared by EU's statistical bureau, Eurostat. ${ }^{22}$

\subsubsection{Changes in the product categories}

New product types require that the product categories must be readjusted. At the readjustments, new groups are established for new products, while product categories of small and decreasing importance no longer are specified at the same degree as before. The readjustments can result in both closing of series, completely new series on a detailed level and changed contents in existing series. This requires control of possible changes when data from recent years is to be used. 



\section{Discussions}

\subsection{Introduction}

The objective of the project has been to develop a method. In order to illustrate the method's applicability, a calculation tool (excel) has been developed in conjunction with the method.

Data from Norway is used to test the method and the tool. It must be emphasized that raw data is not sufficient quality-assured and one cannot expect reliable results. Bearing this reservation in mind, the calculation results are compared with relevant results from other projects and reports.

\subsection{Supply of EEE-products}

In Norway, the Production Register (the EEE-register ${ }^{23}$ ) calculates amounts of EEE-products put on the market based on data of export and import from the Customs and Tax Directory (TAD). TAD is also a source for the Statistic Norway's import and export statistics, which are being used in the project. The domestic production is being reported to the EEE-register from the return companies' member business enterprises. The project has, however, used data on production from the Statistical Central Bureau. For the product categories, which have been included in the project, there is quite a small production in Norway and this difference ought not to have great influence on the calculation results. The calculations on supply of EEE-products accordingly are expected to be almost identical.

Figure 10.1 shows calculations of supply in the project combined with similar calculations from the EEE-register. The total supply amount from the four selected product categories is about 6 percent higher in the EEEregister than in the calculations in the project. The EEE-register has higher figures for the categories 3 (IT and telecommunications equipment) and 7 (Toys, leisure and sports equipment), but lower for category 2 (Small household appliances) and 4 (Consumer equipment).

\footnotetext{
${ }^{23} \mathrm{http}: / /$ www.ee-register.no
} 


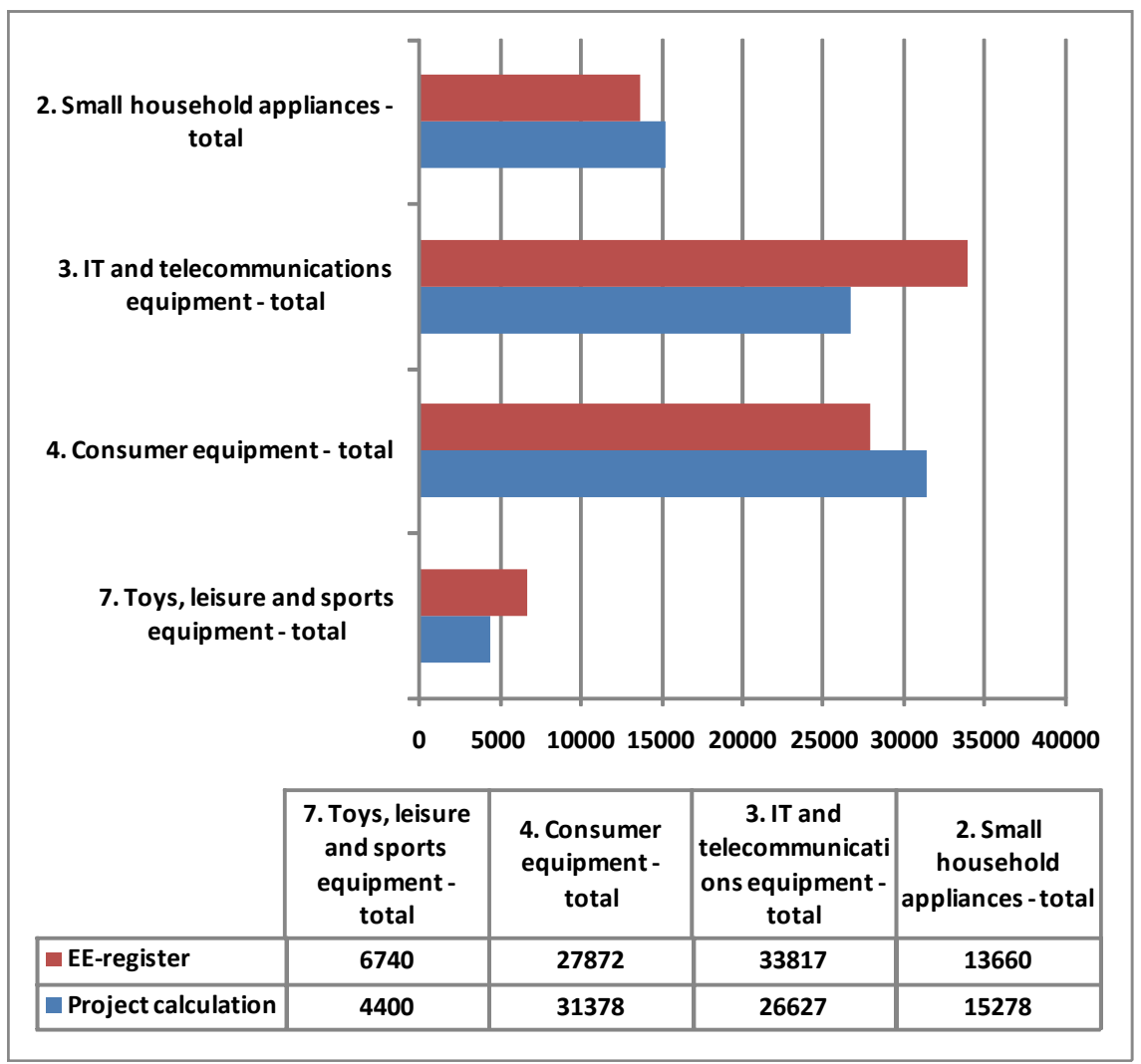

Figure 10.1. Calculated amounts of EEE-products put on market in Norway, 2007. Tonnes.

That relatively great difference between the calculations could be a result of differences in domestic production, despite our expectations. The results also emphasize the necessity of making a qualified and thorough review of input data for the calculations.

\subsection{Waste amount}

\subsubsection{The product categories}

The calculations in the project give a total waste amount of the four product categories of approx. 64.000 ton in Norway in 2007 (figure 2). The amounts increase from approx. 46.000 ton in 2000 corresponding to an increase of 37 percent). There is an increase in all product categories, but highest increase rate is for category 4 (Consumer equipment) with 57 percent. The lowest increase (30 percent) is the one for category 3 (IT and telecommunications equipment).

As previously indicated, the calculation results can only be regarded as indicative in connection with the test method. Nevertheless it is interesting to compare the results with previous and other Norwegian calcula- 
tions. It would also be interesting to compare the results with collected amount of EEE-waste in Norway.

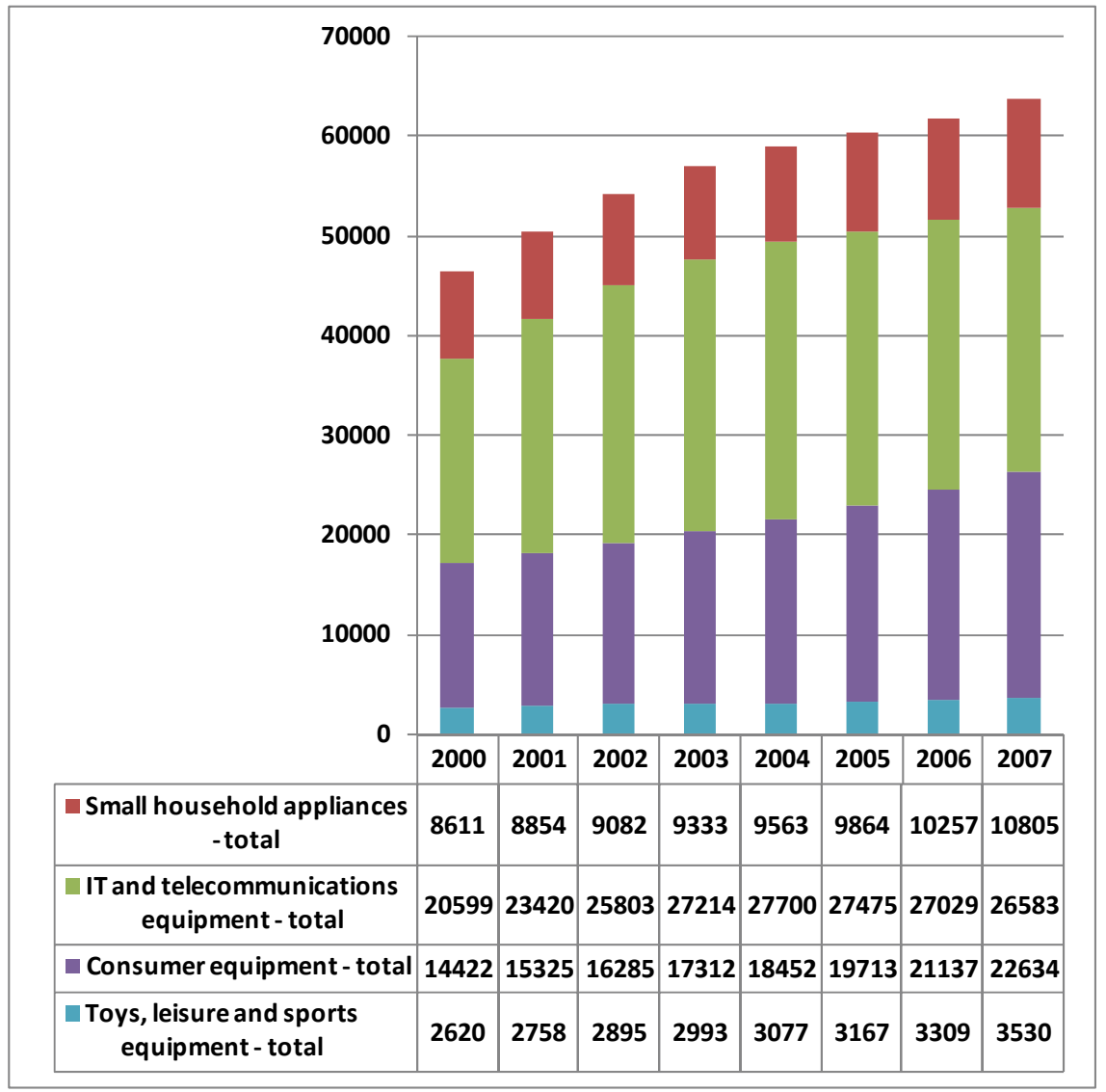

Figure 10.2. Calculated amounts of WEEE in Norway, 2000-2007. Tonnes.

Figure 10.3 shows the calculation results compared with reported figures on collected amounts from all the return companies in $2007^{23}$. Reported collection was 43.129 ton in $2007^{23}$. This equals 72 percent of the calculated generated amount in the project (63 552 ton). The difference is largest for category 7 (Toys, leisure and sports equipment) and category 2 (Small household appliances) where the collected amount is approx. 50 percent of the calculated amount. Category 4 (Consumer equipment) both have a collected amount of approx. 65 percent, while category 3 (IT and telecommunications equipment) has about 80 percent. The differences between the categories seem reasonable since it is well-known that it is difficult to obtain a high collection degree for category 7 , whereas it has been easier to obtain a high collection for category 3 . 


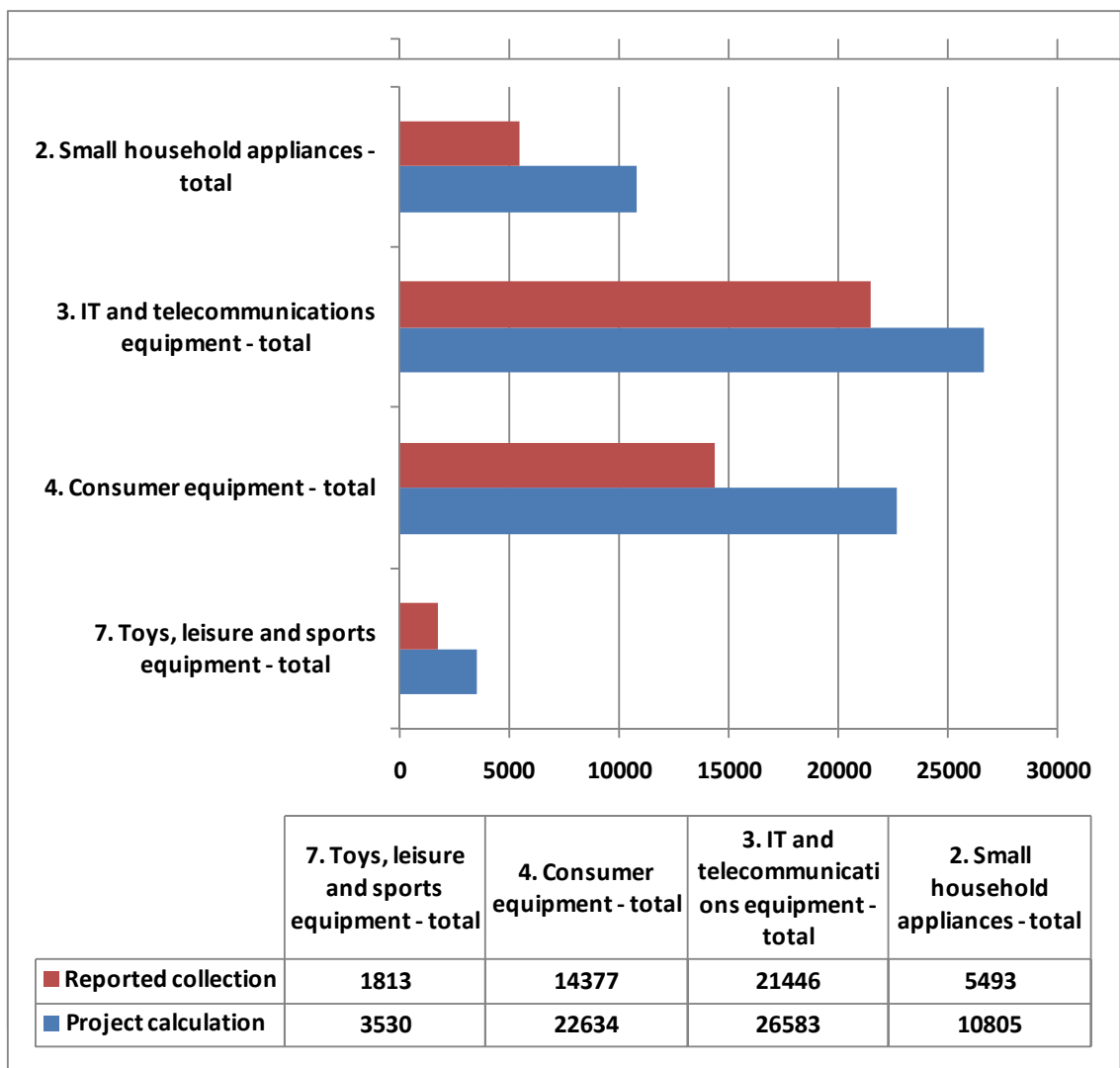

Figure 10.3. Calculated and reported amounts of WEEE in Norway, 2007. Tonnes.

The differences between collected WEEE and the theoretical calculated amount of WEEE are larger than what the return companies in Norway state as collection degree. According to their figures, the collection percent in Norway is about 100 percent WEEE. However, they base their collection degrees on calculations dating back to 1998 (se next section), which are extremely outdated.

The Ministry of Environment ${ }^{24}$ in Norway in 1998 made a calculation of gross amounts of WEEE generated in Norway in the years 1996 to 1999. There is a relatively good coherence in the combination of products in the categories in the report above-mentioned and the categories in used the project. The results of the two calculations accordingly ought to be comparable.

Figure 10.4 shows the project calculations (year 2000) combined with the report to the Environmental Department (year 1999). There is a great degree of coherence between the two calculations. Some of the differences can be attributed to the fact that the calculations apply to two odd years (1999 and 2000).

\footnotetext{
${ }^{24}$ Department of Environment, Norway (1998). Electric and electronic waste (Elektrisk og elektronisk avfall). Hjellnes Cowi AS, February 2008.
} 


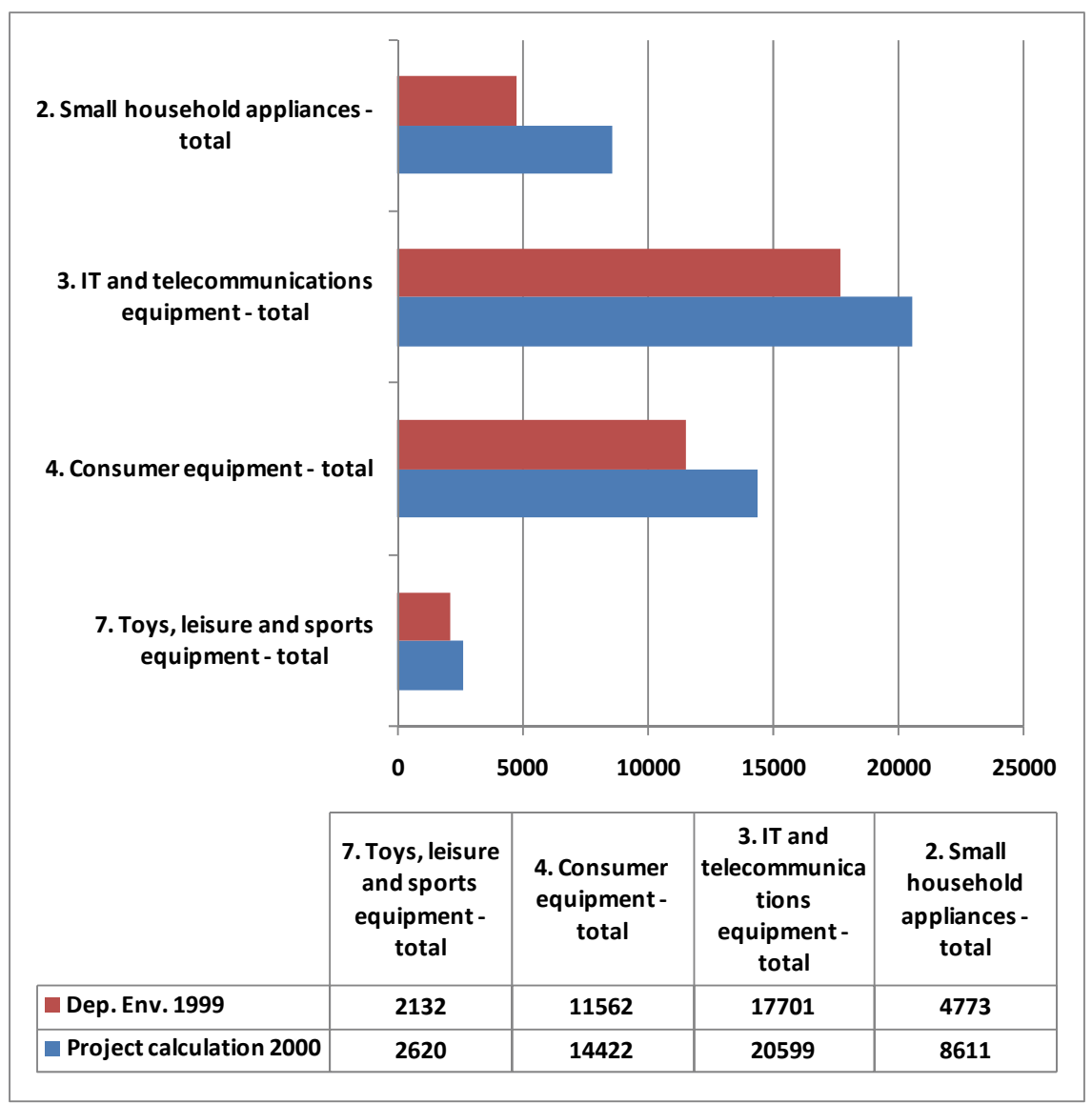

Figure 10. 4. Calculated and reported amounts of WEEE in Norway, 2007. Tonnes.

\subsubsection{Individual products}

The product categories are totals of many individual products and the calculation result is accordingly rather sturdy against errors in the data basis. The results for the individual products are on the other hand more sensitive to errors in the data basis. The amount put on the market can be uncertain and often shows yearly fluctuations. When the waste amounts are calculated, the lifetime profile will, however, level out yearly differences. The long-term trend is on the contrary of great importance for the result. 


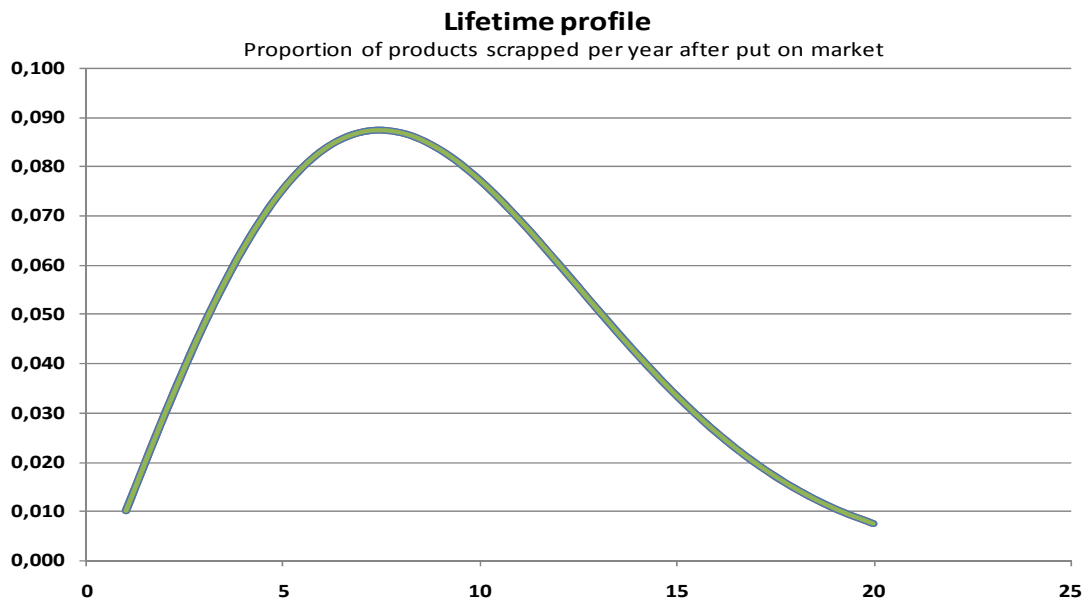

Amount put on market, tonnes

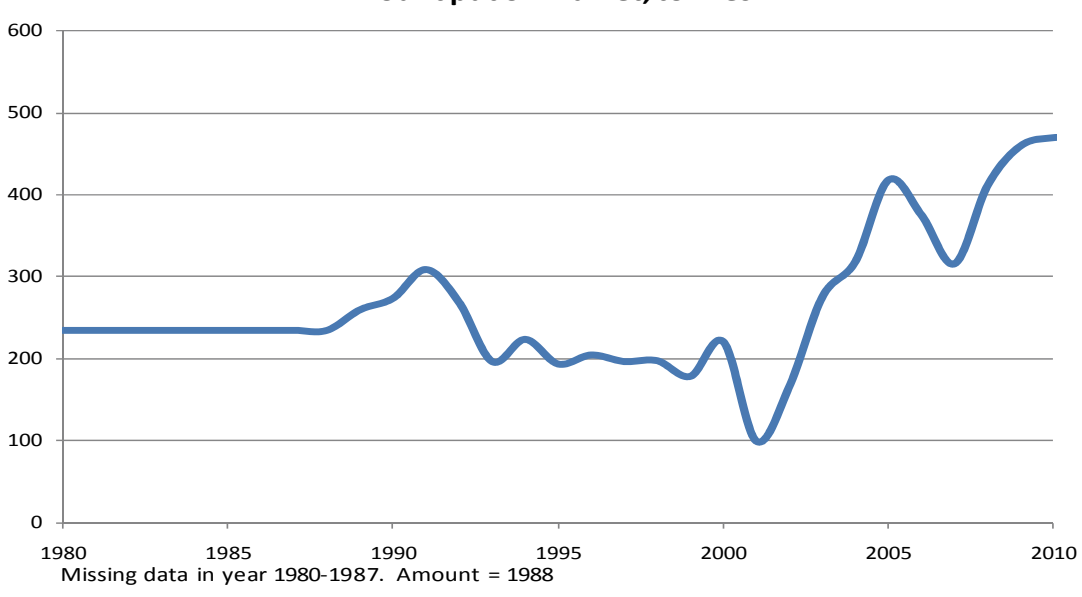

WEEE amount, tonnes

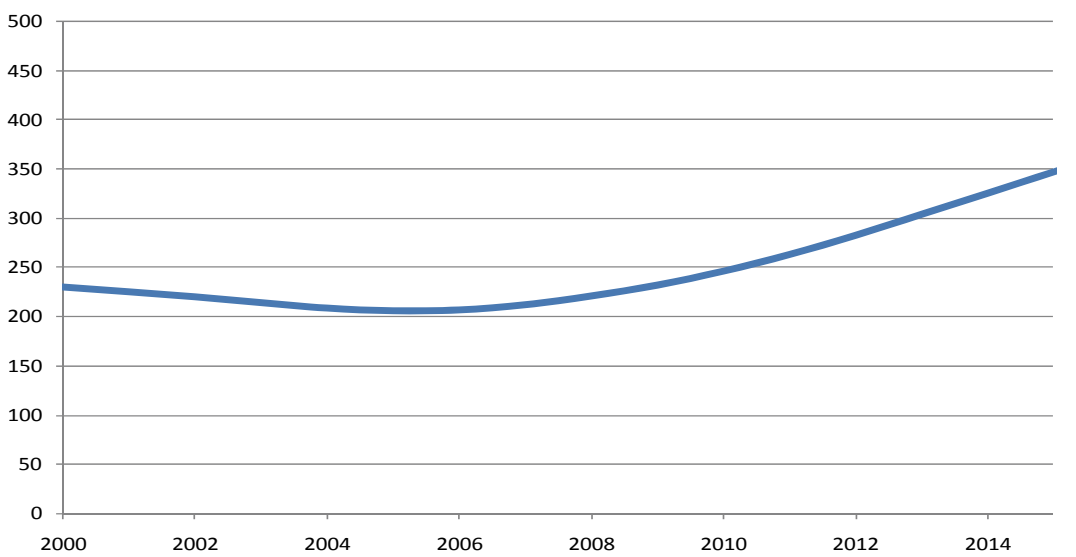

Figure 10.5. Calculations for sewing machines, Norway.

Figure 10.5 illustrates this for the product sewing machines in Norway. The first figure shows the lifetime distribution (profile) for the sewing machines calculated out of the results from the Delphi surrey. The distribution has a modal value of $7-8$ years, meaning that most products turn into waste as this age. However, the distribution is not very narrow and as 
many as 80 percent of the products having between 4 and 13 years lifetime.

The next figure in 10.5 shows the calculated supply of products put on the Norwegian market in the period 1980 to 2010. There are relatively great fluctuations of approx. 100 ton in 1999 up to 460 ton in 2007.

The last figure in 10.5 shows the calculated amounts of waste as a result of the two figures above. The waste amounts have a very smooth progress, quite unlike the supply of products. This is a result of a rather powerful bonding effect of the lifetime distribution.

\subsubsection{Conclusions and recommendations}

Despite insufficient quality check of the supply data used in this report, the calculations show results that are rather consistent with other calculations and data sources. However, the results emphasize the necessity of making a qualified and thorough review of input data for the calculations. The use of lifetime profiles in the calculations results in more reliable and dynamic waste calculations than would be the result with fixed average lifetimes. However, reliable lifetime profiles are not available for most products. To take full advantage of the method effort must be laid in obtaining lifetime profiles.

The calculation tool (excel) implements the method and makes it possible to explore the dynamics of waste amounts generated as a result of product supply and lifetime profiles. The tool is supplied with lifetime profiles obtained in this project and supply data from Norway, The tool is also flexible to calculations based on user-edited data too. 



\section{References}

Bjørn Magnus Iversen (2007). Dynamic material stocks and flows analysis of refrigerant appliances in the Norwegian Waste Electrical and Electronic Equipment (WEEE) system. Master's thesis Trondheim, Juni 2007.

Danish Environmental Protection Agency (1992). Scrapning of electronic equipment (Skrotning af elektroniske apparater), Working paper, Arbejdsrapport Nr. 18, 1992, Miljøstyrelsen.

Danish Environmental Protection Agency (1995). Electric and electronic products. (Elektriske og elektroniske produkter), Arbejdsrapport Nr. 53, 1995.

Danish Environmental Protection Agency (2002). Environmetal consequences of life time extensions of electronic products (Miljøkonsekvenser af levetidsforlængelse af elektroniske produkter), Arbejdsrapport Nr. 18, 2002 Miljøstyrelsen.

Danish Environmental Protection Agency (2002). Armed epoxy and polyethen plastics - consumption and waste amounts (Armeret epoxy og polyesterplast, prognoser). Miljøprojekt 656, 2002

Danish Environmental Protection Agency (2005). Statutory order on Electronic waste (Orientering om elskrotbekendtgørelsen), Environmental Review 2. november 2005, Miljøstyrelsen.

Danish Environmental Protection Agency (2006). A model for projection of ISAG Data, FRIDA (En Model til Fremskrivning af Isag Data, FRIDA), Frits Møller Andersen og Helge V. Larsen, Arbejdsrapport nr. 35, Danish Environmental Protection Agency 2006.

Department of Environment, Norway (1998). Electric and electronic waste (Elektrisk og elektronisk avfall). Hjellnes Cowi AS, February 2008.

EC (2002). Directive 2002/96/EC of the European Parliament and of the Council of 27 January 2003 on waste electrical and electronic equipment (WEEE).

EC (2006). Implementation of the Waste Electrical and Electronic Equipment Directive in the EU, EUR $22231 \mathrm{EN}$, European Communities, European
Commission Joint Research Centre 2006.

EC (2007). The Producer Responsibility Principle of the WEEE Directive. European Commission Environment DG ENV 19 August 2007.

ETC/RWM (2005). Outlook for waste and material flows - Baseline and alternative scenarios, ETC/RWM working paper 2005/1

ETC/RWM (2007). Environmental InputOutput Analyses based on NAMEA data. ETC/RWM working paper 2007/2.

Friends of the Earth Europe and the European Environmental Bureau (2006). Lost in transposition, A study of the implementation of individual producer responsibility in the WEEE Directive, Commissioned by Greenpeace, 2006.

http:/ec.europa.eu/eurostat/ramon/relations/ index.cfm?TargetUrl=LST_REL\&Str LanguageCode=EN\&IntCurrentPage=4 http://en.wikipedia.org/wiki/Delphi_method http://www.ee-register.no

http://www.weibull.com/LifeDataWeb/ lifedataweb.htm\#the_weibull_distribution.htm

Nordic Council of Ministers (2003). Statistics on Waste Electrical and Electronic Equipment, TemaNord 2003:545.

Renas AS (2003). Waste estimates of EEE products within the responsibility of RENAS AS (EE-avfallsanslag innenfor Renas sitt ansvarsområde). Hjellnes COWI AS, Oktober 2003.

Soline Van Wymeersch (2007). Dynamic material flow analysis of selected components and hazardous substances in televisions. Master's thesis Trondheim, June 2007

Statistic Norway (1999). Projection of waste amounts and environmental impact connected to final waste treatment (Framskrivning av avfallsmengder og miljøbelastninger knyttet til sluttbehandling av avfall). Rapporter (RAPP 1999/32)

Statistic Norway (2004). Projection of organic waste 2001-2020 (Framskrivninger av organisk avfall for 20012020). Notater 2004/38 
Statistics Denmark (2004). New data on household's car fleet (Nye data for husholdningers bilpark), Working paper. Danmarks Statistik 12, februar 2004.

The Swedish Dairy Industry (2005). 2010 - A Delphi Study (Den svenska mejeribranschen år 2010 - En delfi studie).
Frederik von Unge, Department of

Business Studies, Uppsala 2005

United Nations University (2007). 2008

Review of Directive 2002/96 on Waste

Electrical and Electronic Equipment (WEEE). Final Report 


\section{Sammendrag}

Elektrisk og og elektronisk avfall (WEEE) består av miljøproblematiske stoffer samt verdifulle materialer. Følgelig har det høy prioritet å redusere miljøproblemer forbundet med avfallet. EU vedtok i 1992 et direktiv som gir produsenter av elektrisk og elektronisk utstyr (EEE) ansvaret for innsamling og behandling av WEEE. Hovedprinsippet i WEEE-direktivet er å forbedre alle operasjoner som bidrar i EE-produkternes livsløp.

For kontroll, planlegging og avfallshåndtering behøver myndigheter og andre relevante parter (produsenter, retur selskaper, operatører) å forutse hvor mye WEEE som oppstår. Så langt er der ingen gode metoder for å beregne mengde WEEE. En beregningsmetode vil gjøre det lettere å sammenligne og utveksling av erfaringer mellom landene. Dessuten endres mengden WEEE som oppstår over tid som følge av endringer i bruken av EEE. Følgelig må tallene oppdateres jevnlig.

\section{Målet med prosjektet}

Hovedhensikten med dette prosjekt er å etablere en metode for å beregne mengden generert avfall av elektrisk og elektronisk utstyr (WEEE). Arbeidet er finansiert av Nordisk Ministerråd og er utført av konsulentselskapene Econet AS i Danmark og Mepex Consult AS i Norge.

Et bredt spekter av brukere kan være målgruppe for metoden: myndigheter, returselskaper, så vel som konsulenter og rådgivere. Det er forutsat at metoden bør være aktuelt for ulike bruker med ulike kvalifikasjoner. Derved må enkelhet og åpenhet vektlegges.

Beregningene er gjort for utvalgte produkter basert på historisk tilførsel av nye produkter og produktenes levetidsfordeling. Metoden er utviklet for beregninger på nasjonalt nivå i henhold til produktkategorier i EUs WEEE-direktivet.

Metoden er implementert i et praktisk verktøy med data fra Norge. Excel har blitt brukt som programvare. Verktøy er tilgjengelig i en demoversjon beregnet for dokumentasjon og demonstrasjon, men kan også brukes til faktiske beregninger når data er tilgjengelig.

Rapporten er strukturert på en slik måte at den reflekterer de enkelte trinn i metodens utvikling. Elementene er beskrevet kort siden den en stor innsats har blitt satt i utvikling av et praktisk verktøy. 


\section{Utviklingen av metoden}

En litteraturgjennomgang med hovedvekt på nordisk litteratur er gjennomført for å få innspill til utviklingen av metoden. Gjennomgangen avdekket flere metoder fra det enkle til det mer kompliserte. Internasjonalt pågår et større arbeid for å utvikle metoder for framskriving av avfall generelt og spesielt for EE-avfall. Flere av disse metodene tar i bruk kunnskap om vårt forbruk, som avhenger av flere forhold. Ikke minst vår økonomi, men også forbrukeradferd, trender, teknologiutviklingen og produktenes tekniske funksjon og levetid. Kunnskap om disse forholdene over tid blir samlet inn og benyttet i metodene. Hvis forventningene til økonomisk utvikling og forbruk skal tas med i vurdering blir metodene enda mer dynamiske og komplekse. Kun innsamling av slik informasjon alene er en svært ressurskrevende oppgave, og desto mer ressurser kreves til oppdatering.

Andre beregningsmetoder bruker data om forbruk av produktene over tid i kombinasjon med estimert levetid. Slike metoder er mer statiske i sin karakter, men er ofte adskillig lettere å oppdatere. I dette prosjekt er der valgt en enkel metode.

\section{Input data og modell beregning}

Minst to elementer er med å påvirke mengden EE-avfall, og derfor nødvendig for å beregne pålitelig statistikk av elektrisk og elektronisk avfall nemlig: mengder produkter som tilføres markedet (både historiske og fremtidige) samt levetid for de enkelte produkter.

Prosjektet har undersøkt hvilke typer kilder som kan brukes til å gi data over mengder av EEE tilført markedet. Det er konkludert med at minst to kilder finnes, hvorav en er returselskapenes rapporter om mengde ee-produkter tilført markedet, rapporteret av egne medlemmer. Den andre er offisiell statistikk fra de nasjonale statistiske byråer. Forskjellen mellom de to kildene er blant annet tilgjengelighet som ofte er bedre for offisiell statistikk. Et annet problem er at datakilden ikke nødvendigvis omfatter alle produkter. På grunn av taushetsplikten kan det være vanskelig å få tilbake data fra returselskaper. Dessuten kjenner vanligvis ikke returselskapene mengden som tilføres markedet fra gratispassasjerer. Disse vil derimot normalt være inkludert i den offisielle statistikken. Taushetsplikten kan også være problemer knyttet til offisiell statistikk dersom dataene finnes på et detaljert nivå.

Det er valgt å anbefale å bruke data fra det nasjonale statistiske byråer, siden disse dataene er lett tilgjengelige og samtidig at det er mulig å skaffe historiske data.

Prosjektet har også undersøkt hvordan informasjon om levetid på relevante produkter kan innsamles. Det har konkludert at der ikke finnes 
tilgjengelige data. I prosjektet er det valgt å samle data via et ekspert panel som ble oppnevnt i forbindelse med prosjektet.

Prosjektet har brukt Delphi-undersøkelsen som metode siden det ble konkludert med at denne metode raskt kunne tilføre prosjektet levetidsdata. Siden resultatene ikke kan sammenlignes med faktisk kunnskap må resultater vurderes i forhold til hva andre mener er sannsynlig. Metoden er enkel og oversiktlig, og prosjektet anbefaler at metoden også brukes i forbindelse med en mulig oppdatering av det prosjektet.

Informasjon om levetid har blitt samlet inn som levetidspunkter. Ekspertgruppen er spurt om hvor mange år det går før henholdsvis 25, 50, 75 og 90 prosent av de markedsførte mengde er kassert. Av praktiske grunner er levetidsdata bare samlet inn for de produktene som står for mer enn 75 percent av de markedsførte mengder innen en produktkategori. De innsamlede levetidsdata er deretter bearbeidet til kontinuerlige levetidsprofiler ved hjelp av en Weibul funktion.

Beregning av årlige mengder av WEEE av et gitt produkt skjer ved å redusere den markedsførte mengde i samsvar med levetidsprofilen for produktet.

\section{Verktøyet}

Excel-verktøyet er utviklet i prosjektet som en test og illustrasjon av metoden, men kan også brukes til faktiske beregninger om data er tilgjengelig. En veiledning er utarbeidet, som også er inkludert i verktøyet.

Verktøyet inkluderer rådata over mengder ee-produkter tilført markedet i Norge i perioden 1986 til og med 2007. Dataene omfatter 28 ulike produkter i kategoriene 2, 3, 4 og 7 i henhold til WEEE-direktivet. Nye produkter kan legges inn, og eksisterende produkter kan endres og lagres. Verktøyet inneholder også et sett av levetidsprofiler, som er samlet inn i prosjektet i 2008. De samme levetidesprofiler brukes på historiske data, men verktøyet har muligheten til å bruke flere levetidsprofiler for ulike historiske perioder av det samme produktet.

Beregning av mengden EE-avfall som oppstår i Norge er bare ment å illustrere metoden. Rådata som er benyttet er ikke kvalitetssikret og beregningsresultater bør følgelig betraktes som veiledende.

\section{Resultater og diskusjon}

Til tross for begrenset kvalitetssikring av data viser resultatene ganske stort samsvar med andre beregninger og datakilder. Derved kan det konkluderes at metoden og verktøyet har vist seg å være funksjonelle. Likevel framhever resultatene nødvendigheten av å gjøre en kvalifisert og grundig vurdering av input data for beregningene. 
Bruk av levetidesprofiler i beregningene gir mer pålitelige og dynamiske beregninger enn det som ville bli resultatet med fast gjennomsnittlig levetid. Pålitelige levetidsprofiler er imidlertid ikke tilgjengelig for de fleste produkter. For å få fullt utbytte av metoden må innsats legges i å fremskaffe levetidsprofiler.

Det må understrekes at oppdragspartene (Mepex A / S og Econet AS) fraskriver seg ansvaret for hvordan en tredjepart kan bruke verktøyet og resultatene. Målet med prosjektet har utelukkende vært å utvikle en metode for beregning. 


\section{Appendices}

1. Cover letter to questionnaire

2. Delphi questionnaire

3. Calculated lifetimes for selected products

4. Modelling scrap data Weibull

5. EEE commodities and positions

6. Supply amounts

7. Waste amounts

8. Guidance for the calculation tool (in separate document)

\section{Appendix 1. Cover letter to questionnaire}

Hjælp os med at skaffe levetider på elektriske og elektroniske produkter Til et metodeprojekt har vi behov for at kende produkters levetider. Vi vil indsamle disse data ved at spørge særlig udvalgte personer inden for branchen. Vi tror at du med din baggrund kan give et værdifuldt bidrag til dette projekt.

Hvad skal jeg mene om levetider

Det er ikke et spørgsmål om konkret nøjagtig viden, men din egen subjektive opfattelser af produktets levetid. Dine svar skal ikke underbygges af talmateriale - og der skal ikke gives nogle konkrete referencer til egen virksomhed eller produkter. Spørgsmålene vil ikke nødvendigvis være knyttet til den del af produktspektret som du har bedst kendskab til i arbejdsmæssig sammenhæng.

Fremgangsmåde

Vi fremsender et spørgeskema. Vi sammenstiller dit svar på levetider med et samlet svar fra de øvrige deltagere. Sammenstillingen returnerer vi til dig for at høre om du ønsker at revidere dine første svar. Deltagernes navne og svar vil være anonyme. Kun konsulenterne kender de enkelte medlemmer.

Hvem har iværksat metodeprojektet

Gruppen for elektrisk og elektronisk affald under Nordisk Ministerråd har iværksat projektet. Der skal udvikles et værktøj, der kan beregne den fremtidige mængde af elektrisk og elektronisk affald. Dette kræver kendskab til mængden af markedsførte produkter samt produkters levetider. 
Projektet gennemføres i et samarbejde mellem miljøkonsulenterne Mepex A/S i Norge og Econet AS i Danmark.

Din vurdering af levetider er vigtig

Vi har fået oplyst dit navn af .......Vi vedlægger et spørgeskema, som vi ønsker besvaret i løbet af den kommende uge. Din arbejdsindsats indskrænker sig til 10-15 minutter.

Du er naturligvis også velkommen til at kontakte undertegnede på telefon: 45882096 eller på e-mail econet@econet.dk.

Med venlig hilsen

Econet AS

Ole Kaysen 


\section{Appendix 2. Delphi questionnair}

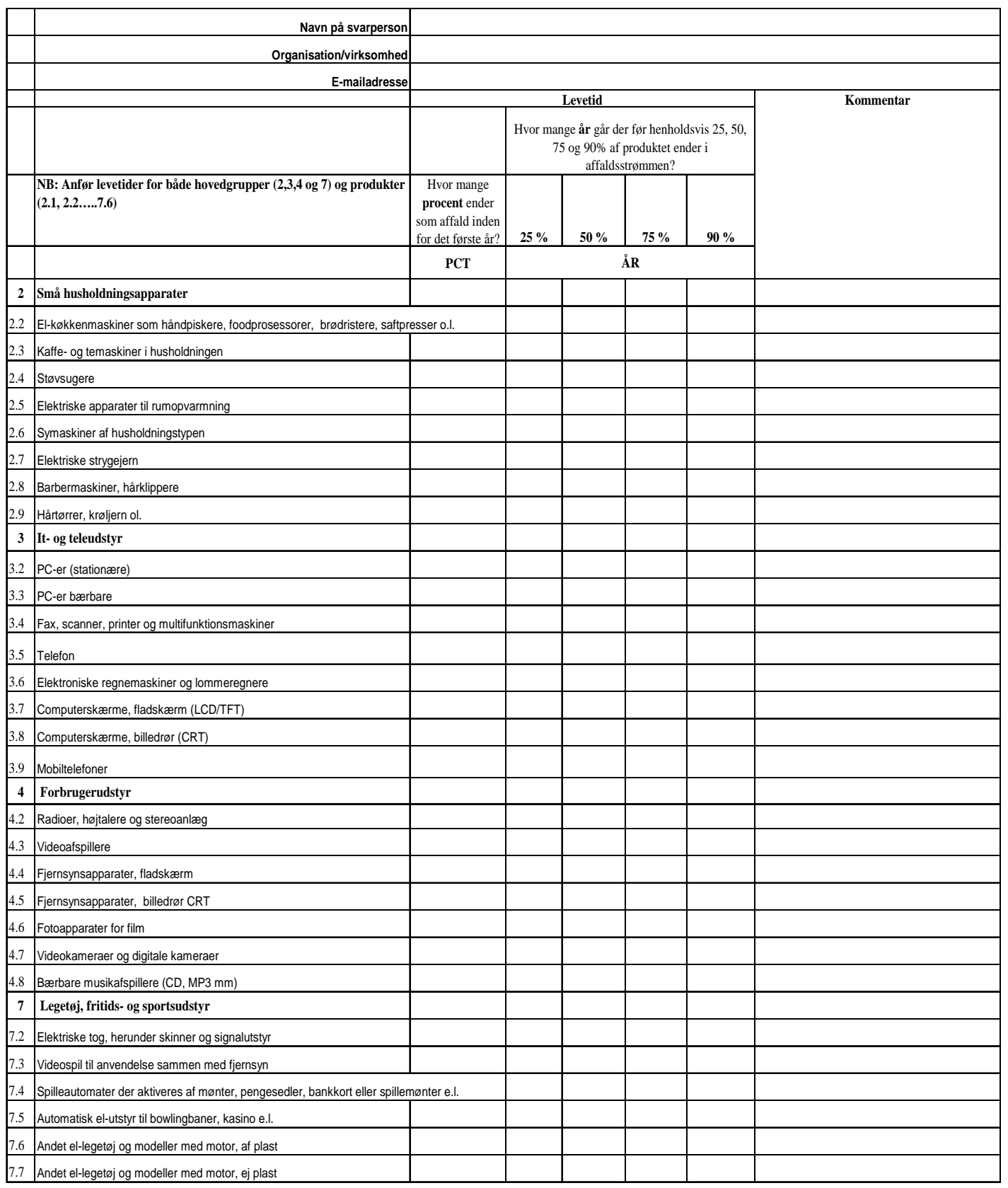




\section{Appendix 3. Calculated lifetimes}

Lifetime datapoints. Delphi survey

\begin{tabular}{|c|c|c|c|c|c|c|}
\hline $\mathrm{pNr}$ & Produkt & D1 & d25 & d50 & d75 & d90 \\
\hline $2-00$ & Small household appliances - total & 5 & 3 & 5 & 7 & 9 \\
\hline $2-01$ & Small household appliances - other & 5 & 3 & 5 & 7 & 9 \\
\hline $2-02$ & Kitchen blenders, foodprosessors, toasters, juice press etc. & 6 & 3 & 5 & 7 & 9 \\
\hline $2-03$ & Koffee- and tea boilers, perculators & 6 & 3 & 4 & 6 & 7 \\
\hline $2-04$ & Vacuum cleaners & 4 & 4 & 6 & 8 & 10 \\
\hline $2-05$ & Room heaters & 3 & 4 & 6 & 8 & 11 \\
\hline $2-06$ & Sewing machine for households & 2 & 5 & 8 & 11 & 15 \\
\hline $2-07$ & Irons & 5 & 3 & 5 & 7 & 9 \\
\hline $2-08$ & Electric razors and haircutters & 6 & 3 & 5 & 6 & 7 \\
\hline 2-09 & Electric hair dryers & 9 & 2 & 4 & 6 & 7 \\
\hline $3-00$ & IT and telecommunications equipment - total & 4 & 3 & 4 & 6 & 7 \\
\hline $3-01$ & IT and telecommunications equipment - other & 5 & 3 & 4 & 5 & 7 \\
\hline $3-02$ & Desktop pc & 3 & 3 & 4 & 5 & 7 \\
\hline $3-03$ & Laptop pc & 3 & 3 & 4 & 5 & 7 \\
\hline $3-04$ & Fax, scanner, printer og multifunction printer & 5 & 3 & 4 & 5 & 7 \\
\hline 3-05 & Telephones and equipent & 6 & 3 & 5 & 7 & 9 \\
\hline $3-06$ & Calculators & 7 & 3 & 5 & 6 & 8 \\
\hline $3-07$ & Computer monitor, flatscreen (LCD/TFT) & 3 & 3 & 4 & 5 & 7 \\
\hline $3-08$ & Computer monitor, cathode ray tube (CRT) & 3 & 3 & 4 & 5 & 7 \\
\hline 3-09 & Mobile phones and equipement & 9 & 2 & 3 & 4 & 4 \\
\hline $4-00$ & Consumer equipment - total & 3 & 4 & 5 & 7 & 9 \\
\hline 4-01 & Consumer equipment - other & 4 & 3 & 5 & 7 & 9 \\
\hline $4-02$ & Radios, hifi systems, speakers & 4 & 4 & 6 & 8 & 10 \\
\hline $4-03$ & Video players and recorders & 3 & 3 & 5 & 6 & 8 \\
\hline $4-04$ & Television, flatscreen (LCD/Plasma) & 3 & 4 & 6 & 7 & 9 \\
\hline $4-05$ & Television, cathode ray tube (CRT) & 3 & 4 & 6 & 7 & 10 \\
\hline 4-06 & Cameras for use with photographic film & 4 & 3 & 5 & 7 & 9 \\
\hline $4-07$ & Camcorders and digital cameras & 4 & 3 & 5 & 6 & 8 \\
\hline $4-08$ & Portable music players (CD, MP3 etc) & 5 & 2 & 3 & 4 & 5 \\
\hline $7-00$ & Toys, leisure and sports equipment - total & 4 & 3 & 5 & 7 & 9 \\
\hline $7-01$ & Toys, leisure and sports equipment - other & 5 & 3 & 5 & 7 & 9 \\
\hline $7-02$ & Electric trains, incl. rails and signalequipment & 3 & 5 & 7 & 10 & 13 \\
\hline $7-03$ & Video games for use with television & 6 & 3 & 4 & 5 & 7 \\
\hline $7-04$ & Slot Machines & 2 & 3 & 5 & 8 & 11 \\
\hline $7-05$ & Electric equipment for bowling alley, casinos etc. & 2 & 3 & 5 & 8 & 10 \\
\hline 7-06 & Other electric toys and models with engines, plastic & 9 & 2 & 3 & 5 & 6 \\
\hline 7-07 & Other electric toys and models with engines, excluding plastic & 8 & 2 & 3 & 5 & 6 \\
\hline
\end{tabular}

$\mathrm{d} 1=$ Percentage which ends up as waste within the first year $\mathrm{d} 25, \mathrm{~d} 50, \mathrm{~d} 75, \mathrm{~d} 90=$ year when $25 \%, 50 \%, 75 \%, 90 \%$ of the products is scrapped 


\section{Calculated lifetime distributions}

\begin{tabular}{|c|c|c|c|c|c|c|c|c|c|c|c|c|}
\hline $\mathrm{pNr}$ & Produkt & 11 & 12 & & 13 & 14 & 15 & 16 & 17 & 18 & 19 & 20 \\
\hline $2-00$ & Small household appliances - total & 0,000 & 0,000 & & 0,000 & 0,000 & 0,000 & 0,000 & 0,000 & 0,000 & 0,000 & 0,000 \\
\hline 2-01 & Small household appliances - other & 0,027 & 0,018 & & 0,012 & 0,008 & 0,006 & 0,004 & 0,003 & 0,002 & 0,001 & 0,001 \\
\hline $2-02$ & Kitchen blenders, foodprosessors, toasters, juic & 0,026 & 0,015 & & 0,008 & 0,004 & 0,002 & 0,001 & 0,000 & 0,000 & 0,000 & 0,000 \\
\hline $2-03$ & Koffee- and tea boilers, perculators & 0,004 & 0,001 & & 0,000 & 0,000 & 0,000 & 0,000 & 0,000 & 0,000 & 0,000 & 0,000 \\
\hline $2-04$ & Vacuum cleaners & 0,037 & 0,022 & & 0,012 & 0,006 & 0,003 & 0,001 & 0,001 & 0,000 & 0,000 & 0,000 \\
\hline $2-05$ & Room heaters & 0,048 & 0,033 & & 0,021 & 0,013 & 0,007 & 0,004 & 0,002 & 0,001 & 0,000 & 0,000 \\
\hline $2-06$ & Sewing machine for households & 0,069 & 0,060 & & 0,051 & 0,042 & 0,034 & 0,026 & 0,020 & 0,015 & 0,011 & 0,008 \\
\hline $2-07$ & Irons & 0,025 & 0,013 & & 0,006 & 0,002 & 0,001 & 0,000 & 0,000 & 0,000 & 0,000 & 0,000 \\
\hline $2-08$ & Electric razors and haircutters & 0,005 & 0,001 & & 0,000 & 0,000 & 0,000 & 0,000 & 0,000 & 0,000 & 0,000 & 0,000 \\
\hline $2-09$ & Electric hair dryers & 0,005 & 0,002 & & 0,000 & 0,000 & 0,000 & 0,000 & 0,000 & 0,000 & 0,000 & 0,000 \\
\hline $3-00$ & IT and telecommunications equipment - total & 0,000 & 0,000 & & 0,000 & 0,000 & 0,000 & 0,000 & 0,000 & 0,000 & 0,000 & 0,000 \\
\hline 3-01 & IT and telecommunications equipment - other & 0,007 & 0,003 & & 0,001 & 0,001 & 0,000 & 0,000 & 0,000 & 0,000 & 0,000 & 0,000 \\
\hline 3-02 & Desktop pc & 0,002 & 0,000 & & 0,000 & 0,000 & 0,000 & 0,000 & 0,000 & 0,000 & 0,000 & 0,000 \\
\hline 3-03 & Laptop pc & 0,002 & 0,000 & & 0,000 & 0,000 & 0,000 & 0,000 & 0,000 & 0,000 & 0,000 & 0,000 \\
\hline $3-04$ & Fax, scanner, printer og multifunction printer & 0,003 & 0,001 & & 0,000 & 0,000 & 0,000 & 0,000 & 0,000 & 0,000 & 0,000 & 0,000 \\
\hline 3-05 & Telephones and equipent & 0,028 & 0,016 & & 0,009 & 0,005 & 0,002 & 0,001 & 0,000 & 0,000 & 0,000 & 0,000 \\
\hline $3-06$ & Calculators & 0,014 & 0,006 & & 0,002 & 0,001 & 0,000 & 0,000 & 0,000 & 0,000 & 0,000 & 0,000 \\
\hline 3-07 & Computer monitor, flatscreen (LCD/TFT) & 0,002 & 0,001 & & 0,000 & 0,000 & 0,000 & 0,000 & 0,000 & 0,000 & 0,000 & 0,000 \\
\hline $3-08$ & Computer monitor, cathode ray tube (CRT) & 0,003 & 0,001 & & 0,000 & 0,000 & 0,000 & 0,000 & 0,000 & 0,000 & 0,000 & 0,000 \\
\hline 3-09 & Mobile phones and equipement & 0,000 & 0,000 & & 0,000 & 0,000 & 0,000 & 0,000 & 0,000 & 0,000 & 0,000 & 0,000 \\
\hline $4-00$ & Consumer equipment - total & 0,000 & 0,000 & & 0,000 & 0,000 & 0,000 & 0,000 & 0,000 & 0,000 & 0,000 & 0,000 \\
\hline 4-01 & Consumer equipment - other & 0,023 & 0,013 & & 0,007 & 0,004 & 0,002 & 0,001 & 0,000 & 0,000 & 0,000 & 0,000 \\
\hline 4-02 & Radios, hifi systems, speakers & 0,045 & 0,029 & & 0,017 & 0,010 & 0,005 & 0,002 & 0,001 & 0,000 & 0,000 & 0,000 \\
\hline $4-03$ & Video players and recorders & 0,010 & 0,004 & & 0,001 & 0,000 & 0,000 & 0,000 & 0,000 & 0,000 & 0,000 & 0,000 \\
\hline 4-04 & Television, flatscreen (LCD/Plasma) & 0,033 & 0,018 & & 0,010 & 0,004 & 0,002 & 0,001 & 0,000 & 0,000 & 0,000 & 0,000 \\
\hline 4-05 & Television, cathode ray tube (CRT) & 0,033 & 0,019 & & 0,010 & 0,005 & 0,002 & 0,001 & 0,000 & 0,000 & 0,000 & 0,000 \\
\hline 4-06 & Cameras for use with photographic film & 0,029 & 0,017 & & 0,009 & 0,005 & 0,002 & 0,001 & 0,000 & 0,000 & 0,000 & 0,000 \\
\hline 4-07 & Camcorders and digital cameras & 0,013 & 0,006 & & 0,002 & 0,001 & 0,000 & 0,000 & 0,000 & 0,000 & 0,000 & 0,000 \\
\hline 4-08 & Portable music players (CD, MP3 etc) & 0,000 & 0,000 & & 0,000 & 0,000 & 0,000 & 0,000 & 0,000 & 0,000 & 0,000 & 0,000 \\
\hline $7-00$ & Toys, leisure and sports equipment - total & 0,000 & 0,000 & & 0,000 & 0,000 & 0,000 & 0,000 & 0,000 & 0,000 & 0,000 & 0,000 \\
\hline 7-01 & Toys, leisure and sports equipment - other & 0,024 & 0,018 & & 0,013 & 0,009 & 0,006 & 0,004 & 0,002 & 0,001 & 0,001 & 0,000 \\
\hline 7-02 & Electric trains, incl. rails and signalequipment & 0,069 & 0,056 & & 0,043 & 0,031 & 0,022 & 0,015 & 0,009 & 0,006 & 0,003 & 0,002 \\
\hline $7-03$ & Video games for use with television & 0,002 & 0,001 & & 0,000 & 0,000 & 0,000 & 0,000 & 0,000 & 0,000 & 0,000 & 0,000 \\
\hline 7-04 & Slot Machines & 0,039 & 0,028 & & 0,019 & 0,013 & 0,008 & 0,005 & 0,003 & 0,002 & 0,001 & 0,001 \\
\hline 7-05 & Electric equipment for bowling alley, casinos etc & 0,034 & 0,023 & & 0,015 & 0,009 & 0,005 & 0,003 & 0,002 & 0,001 & 0,000 & 0,000 \\
\hline $7-06$ & Other electric toys and models with engines, pla: & 0,001 & 0,000 & & 0,000 & 0,000 & 0,000 & 0,000 & 0,000 & 0,000 & 0,000 & 0,000 \\
\hline 7-07 & Other electric toys and models with engines, exc & 0,001 & 0,000 & & 0,000 & 0,000 & 0,000 & 0,000 & 0,000 & 0,000 & 0,000 & 0,000 \\
\hline $\mathrm{pNr}$ & Produkt & 0 & 1 & 2 & 3 & 4 & 5 & 6 & 7 & 8 & 9 & 10 \\
\hline $2-00$ & Small household appliances - total & 0,000 & 0,000 & 0,000 & 0,000 & 0,000 & 0,000 & 0,000 & 0,000 & 0,000 & 0,000 & 0,000 \\
\hline 2-01 & Small household appliances - other & 0,036 & 0,016 & 0,059 & 0,102 & 0,132 & 0,143 & 0,133 & 0,110 & 0,083 & 0,059 & 0,040 \\
\hline $2-02$ & Kitchen blenders, foodprosessors, toasters, juic & 0,042 & 0,022 & 0,068 & 0,107 & 0,131 & 0,138 & 0,130 & 0,112 & 0,087 & 0,063 & 0,042 \\
\hline $2-03$ & Koffee- and tea boilers, perculators & 0,053 & 0,013 & 0,063 & 0,125 & 0,173 & 0,185 & 0,161 & 0,114 & 0,066 & 0,031 & 0,012 \\
\hline $2-04$ & Vacuum cleaners & 0,021 & 0,014 & 0,051 & 0,088 & 0,117 & 0,133 & 0,134 & 0,123 & 0,103 & 0,079 & 0,056 \\
\hline 2-05 & Room heaters & 0,014 & 0,014 & 0,047 & 0,079 & 0,104 & 0,119 & 0,123 & 0,117 & 0,103 & 0,085 & 0,066 \\
\hline $2-06$ & Sewing machine for households & 0,005 & 0,010 & 0,030 & 0,048 & 0,064 & 0,076 & 0,083 & 0,087 & 0,087 & 0,083 & 0,077 \\
\hline 2-07 & Irons & 0,041 & 0,013 & 0,051 & 0,094 & 0,128 & 0,145 & 0,144 & 0,126 & 0,099 & 0,069 & 0,044 \\
\hline $2-08$ & Electric razors and haircutters & 0,046 & 0,016 & 0,069 & 0,129 & 0,171 & 0,179 & 0,155 & 0,112 & 0,067 & 0,034 & 0,014 \\
\hline 2-09 & Electric hair dryers & 0,064 & 0,026 & 0,091 & 0,146 & 0,173 & 0,167 & 0,135 & 0,093 & 0,056 & 0,029 & 0,013 \\
\hline $3-00$ & IT and telecommunications equipment - total & 0,000 & 0,000 & 0,000 & 0,000 & 0,000 & 0,000 & 0,000 & 0,000 & 0,000 & 0,000 & 0,000 \\
\hline 3-01 & IT and telecommunications equipment - other & 0,016 & 0,029 & 0,107 & 0,170 & 0,189 & 0,168 & 0,129 & 0,087 & 0,052 & 0,028 & 0,014 \\
\hline 3-02 & Desktop pc & 0,007 & 0,018 & 0,082 & 0,153 & 0,199 & 0,199 & 0,158 & 0,102 & 0,052 & 0,021 & 0,007 \\
\hline $3-03$ & Laptop pc & 0,000 & 0,029 & 0,106 & 0,174 & 0,204 & 0,188 & 0,141 & 0,087 & 0,045 & 0,019 & 0,007 \\
\hline 3-04 & Fax, scanner, printer og multifunction printer & 0,008 & 0,030 & 0,107 & 0,171 & 0,198 & 0,182 & 0,138 & 0,087 & 0,047 & 0,021 & 0,008 \\
\hline 3-05 & Telephones and equipent & 0,031 & 0,021 & 0,066 & 0,105 & 0,130 & 0,138 & 0,132 & 0,114 & 0,090 & 0,066 & 0,045 \\
\hline $3-06$ & Calculators & 0,053 & 0,018 & 0,066 & 0,115 & 0,148 & 0,158 & 0,145 & 0,116 & 0,081 & 0,051 & 0,028 \\
\hline 3-07 & Computer monitor, flatscreen (LCD/TFT) & 0,000 & 0,027 & 0,101 & 0,169 & 0,201 & 0,188 & 0,144 & 0,091 & 0,048 & 0,021 & 0,008 \\
\hline $3-08$ & Computer monitor, cathode ray tube (CRT) & 0,000 & 0,028 & 0,101 & 0,166 & 0,196 & 0,185 & 0,143 & 0,093 & 0,051 & 0,024 & 0,009 \\
\hline 3-09 & Mobile phones and equipement & 0,029 & 0,060 & 0,227 & 0,309 & 0,234 & 0,107 & 0,029 & 0,005 & 0,000 & 0,000 & 0,000 \\
\hline $4-00$ & Consumer equipment - total & 0,000 & 0,000 & 0,000 & 0,000 & 0,000 & 0,000 & 0,000 & 0,000 & 0,000 & 0,000 & 0,000 \\
\hline 4-01 & Consumer equipment - other & 0,008 & 0,024 & 0,080 & 0,127 & 0,150 & 0,149 & 0,132 & 0,107 & 0,081 & 0,057 & 0,038 \\
\hline $4-02$ & Radios, hifi systems, speakers & 0,011 & 0,013 & 0,045 & 0,079 & 0,107 & 0,125 & 0,130 & 0,123 & 0,107 & 0,086 & 0,064 \\
\hline $4-03$ & Video players and recorders & 0,004 & 0,025 & 0,086 & 0,140 & 0,169 & 0,170 & 0,146 & 0,109 & 0,072 & 0,042 & 0,022 \\
\hline 4-04 & Television, flatscreen (LCD/Plasma) & 0,010 & 0,014 & 0,051 & 0,091 & 0,123 & 0,140 & 0,141 & 0,128 & 0,104 & 0,078 & 0,053 \\
\hline 4-05 & Television, cathode ray tube (CRT) & 0,009 & 0,014 & 0,052 & 0,092 & 0,123 & 0,140 & 0,141 & 0,127 & 0,104 & 0,077 & 0,053 \\
\hline $4-06$ & Cameras for use with photographic film & 0,009 & 0,021 & 0,067 & 0,106 & 0,132 & 0,141 & 0,135 & 0,117 & 0,093 & 0,068 & 0,046 \\
\hline $4-07$ & Camcorders and digital cameras & 0,002 & 0,030 & 0,092 & 0,140 & 0,164 & 0,161 & 0,139 & 0,106 & 0,073 & 0,045 & 0,025 \\
\hline $4-08$ & Portable music players (CD, MP3 etc) & 0,009 & 0,049 & 0,165 & 0,238 & 0,231 & 0,166 & 0,090 & 0,037 & 0,012 & 0,003 & 0,001 \\
\hline $7-00$ & Toys, leisure and sports equipment - total & 0,000 & 0,000 & 0,000 & 0,000 & 0,000 & 0,000 & 0,000 & 0,000 & 0,000 & 0,000 & 0,000 \\
\hline 7-01 & Toys, leisure and sports equipment - other & 0,023 & 0,033 & 0,096 & 0,139 & 0,153 & 0,140 & 0,113 & 0,085 & 0,062 & 0,045 & 0,033 \\
\hline 7-02 & Electric trains, incl. rails and signalequipment & 0,016 & 0,008 & 0,029 & 0,051 & 0,071 & 0,088 & 0,098 & 0,103 & 0,101 & 0,094 & 0,083 \\
\hline $7-03$ & Video games for use with television & 0,032 & 0,030 & 0,106 & 0,171 & 0,196 & 0,179 & 0,133 & 0,083 & 0,043 & 0,018 & 0,007 \\
\hline 7-04 & Slot Machines & 0,000 & 0,033 & 0,078 & 0,106 & 0,120 & 0,122 & 0,115 & 0,102 & 0,086 & 0,069 & 0,053 \\
\hline 7-05 & Electric equipment for bowling alley, casinos etc & 0,000 & 0,031 & 0,079 & 0,111 & 0,127 & 0,130 & 0,122 & 0,106 & 0,087 & 0,067 & 0,049 \\
\hline 7-06 & Other electric toys and models with engines, pla: & 0,042 & 0,053 & 0,155 & 0,211 & 0,205 & 0,156 & 0,097 & 0,049 & 0,021 & 0,007 & 0,002 \\
\hline 7-07 & Other electric toys and models with engines, exc & 0,045 & 0,042 & 0,130 & 0,188 & 0,197 & 0,165 & 0,114 & 0,066 & 0,032 & 0,013 & 0,005 \\
\hline
\end{tabular}




\section{Appendix 4. Modelling scrap data Weibull}

Klaus Juel Olsenm MSc, PhD

\section{Modelling Scrap Data}

\section{Introduction}

The purpose of modelling the scrap data is, for each product category which will be included, to estimate the amount of scrap per year. This will be accomplished by

a) Estimate the survival distribution (or rather the cumulative distribution function) for each product category

b) Retrieve sales statistics for each product category

c) Combine survival and sales to yield an estimate for future year scrap volumes (numbers).

Survival modelling

The Weibull distribution is a versatile distribution often used for modelling of survival data. For these reasons, it was decided to use the Weibull distribution. A strict statistical check on the optimality of the model choice is difficult with the available data. However, as this project involves uncertainties at many levels which will influence the final estimates, irrespective of the chosen survival model, the actual model choice is believed to be less important.

The data for the survival distributions will come from a Delphi evaluation. Learned individuals will, for each product category, assess

1. Fraction scrapped during the first year

2. Number of years before 25 percent are scrapped

3. Number of years before 50 percent are scrapped

4. Number of years before 72 percent are scrapped

5. Number of years before 90 percent are scrapped

The data basis for the modelling, thus consist of estimates of points on the survival distribution itself. This is in contrast to the more normal situation where observed lifetimes from a population form the data basis. As result, the approach in this modelling will be different.

The cumulative Weibull distribution function, which describes the fraction of items scrapped at time $t$, is defined as

$$
F(t)=1-\exp \left(-\alpha t^{\lambda}\right)
$$

with the parameters $\alpha$ and $\lambda$. 
It is assessed that for some product categories, there may be an increased risk of failure/scrap shortly after purchase. If this is the case, the Weibull distribution may not be sufficiently flexible to model the data. It was therefore decided to model using a compound distribution: An increased risk of failure shortly after purchase, described by the parameter $k_{0}$, and otherwise a Weibull distribution. The compound cumulative distribution thus is

$$
F(t)=k_{0}+\left(1-k_{0}\right)\left(1-\exp \left(-\alpha t^{\lambda}\right)\right)
$$

With the five data points defined above (1. - 5), the three parameters in this model may be estimated. With $Y_{1}$ as the fraction scrapped during the first year the equation becomes

$$
Y_{1}=k_{0}+\left(1-k_{0}\right)(1-\exp (-\alpha))
$$

With $T_{0.25}$ as the number of years before 25 percent are scrapped the second equation becomes

$$
0.25=k_{0}+\left(1-k_{0}\right)\left(1-\exp \left(-\alpha T_{0.25}^{\lambda}\right)\right)
$$

Similar equations are found for the other percentiles. The set of five equations with 3 unknown parameters may be estimated by any standard numerical approach. Let $Y_{1}$ to $Y_{5}$ represent the left hand side of the above equations, and let $T_{1}$ to $T_{5}$ represent the time points for the corresponding right hand side of the equations. Then the optimisation criterion is:

$$
\operatorname{Min}_{k_{0}, \alpha \lambda} \sum_{i=1}^{5}\left(Y_{i}-\mathrm{F}\left(T_{i} ; k_{0}, \alpha, \lambda\right)\right)^{2}
$$

Minimising the MSE by the Excel implemented Newton-Raphson approach was used for simplicity. There are two approaches to handling the response from the Delphi responders. Either, the Y1 to Y5 responses may be averaged across responders and the parameters may be estimated for a product category, or the parameters are estimated for each respondent followed by averaging of the parameters. In a more standard situation, it would be recommended to estimate and then average. However, in this situation it is not known what is the best approach, and average followed by estimation has been chosen for simplicity with excel implementation. If/when a general tool is later developed, estimation followed by averaging may be the preferable approach. 
Estimating scrap volumes

Let the sales volumes be represented by $V_{t}$ with $t$ as the year. The estimated scrap volume in year $t+1, S_{t+1}$, then is

$$
S_{t+1}=\sum_{i=0}^{N} V_{t-i} F_{i+1}
$$

The time unit, years, probably should be considered a bit further. On the one side, it does not make sense to use a shorter time unit (month) since this will not be supported by the available data. On the other hand, there is a slight discrepancy between the survival distribution functions found above, and the sales statistics. For a given year, say 2008, the sales volumes correspond to products sold from January through December. On the other hand, the fraction scrapped during the first year, will for purchases from early January correspond to the year 2008, while for a purchase in late December this will correspond to the year 2009. A similar consideration applies for the later years in the survival distribution. If the sale was constant throughout the year, this problem could be handled by shifting the survival distribution half a year. If for some products, peak sale is during December, shifting by one year will be more appropriate. In conclusion, this question may need more discussion, but in the present version of the excel toll a shift of half a year has been implemented.

Excel implementation

The above model has been implemented in excel. Since the estimate of the survival distribution must be numeric, the Solver function in excel has been used. Note that Solver is not always installed in excel. If not, this is done by choosing Tools, Add-Ins, Solver.

For using the model enter the data for the survival distribution and for the sale volumes. Open solver and click ok to the already existing model. This will update the survival distribution, and give estimates of scrap volumes for future years. The current implementation requires sale volumes for the years 2000 - 2020. The scrap years are shown for the same year range - but only plotted for 2010 - 2020.

Obviously, special attention should be given to the years in the beginning of the range where items purchased prior to the included sales are being scrapped. Similarly, attention should be given to the end of the range, i.e. the future years, when the sales data are only predictions and not realised numbers.

The excel implantation is designed to allow data entry for a single product category. Multiple categories must thus be handled by copying the excel workbook and have a separate workbook for each category. A more refined application may be made that can handle the several product categories simultaneously. 

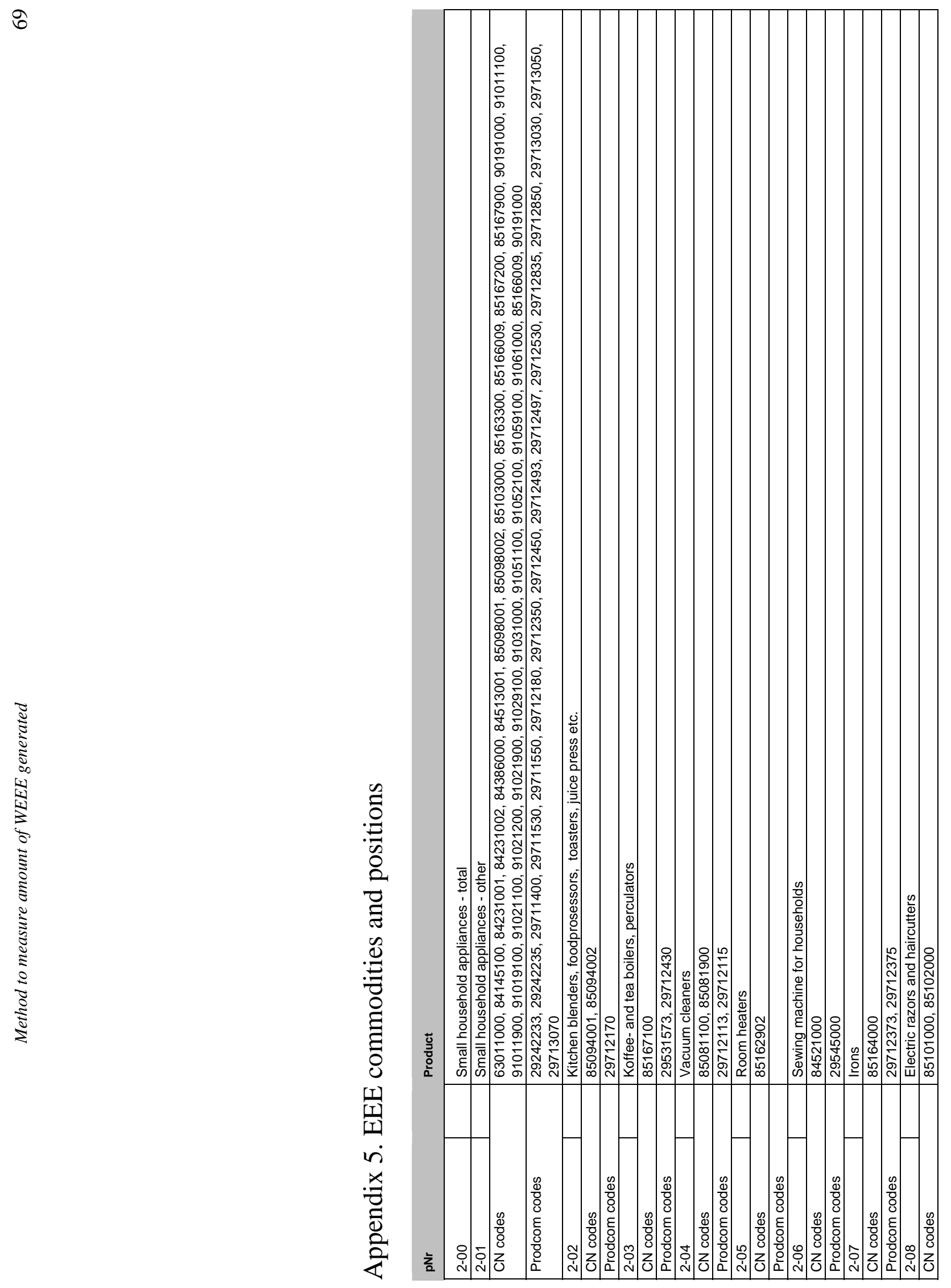


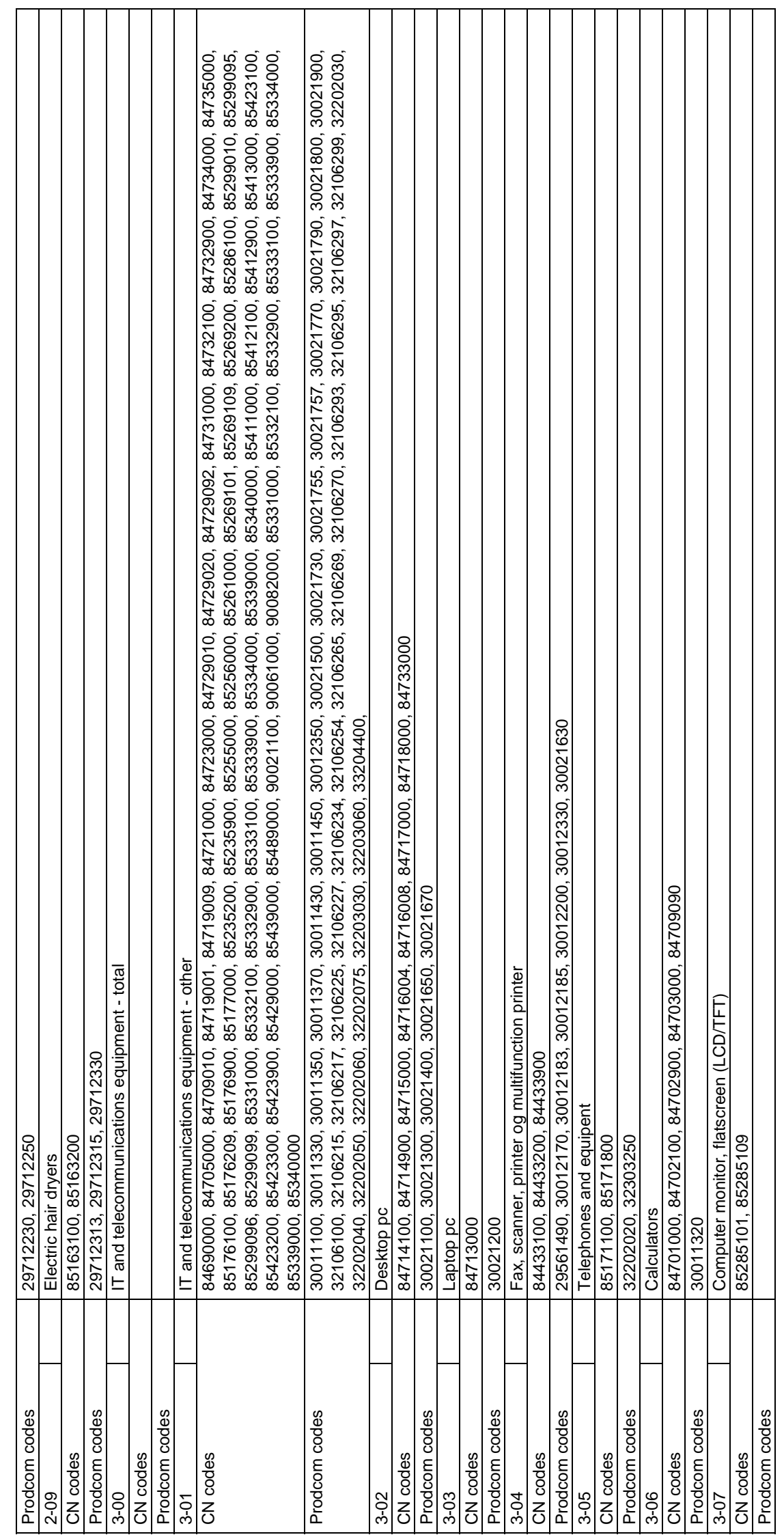




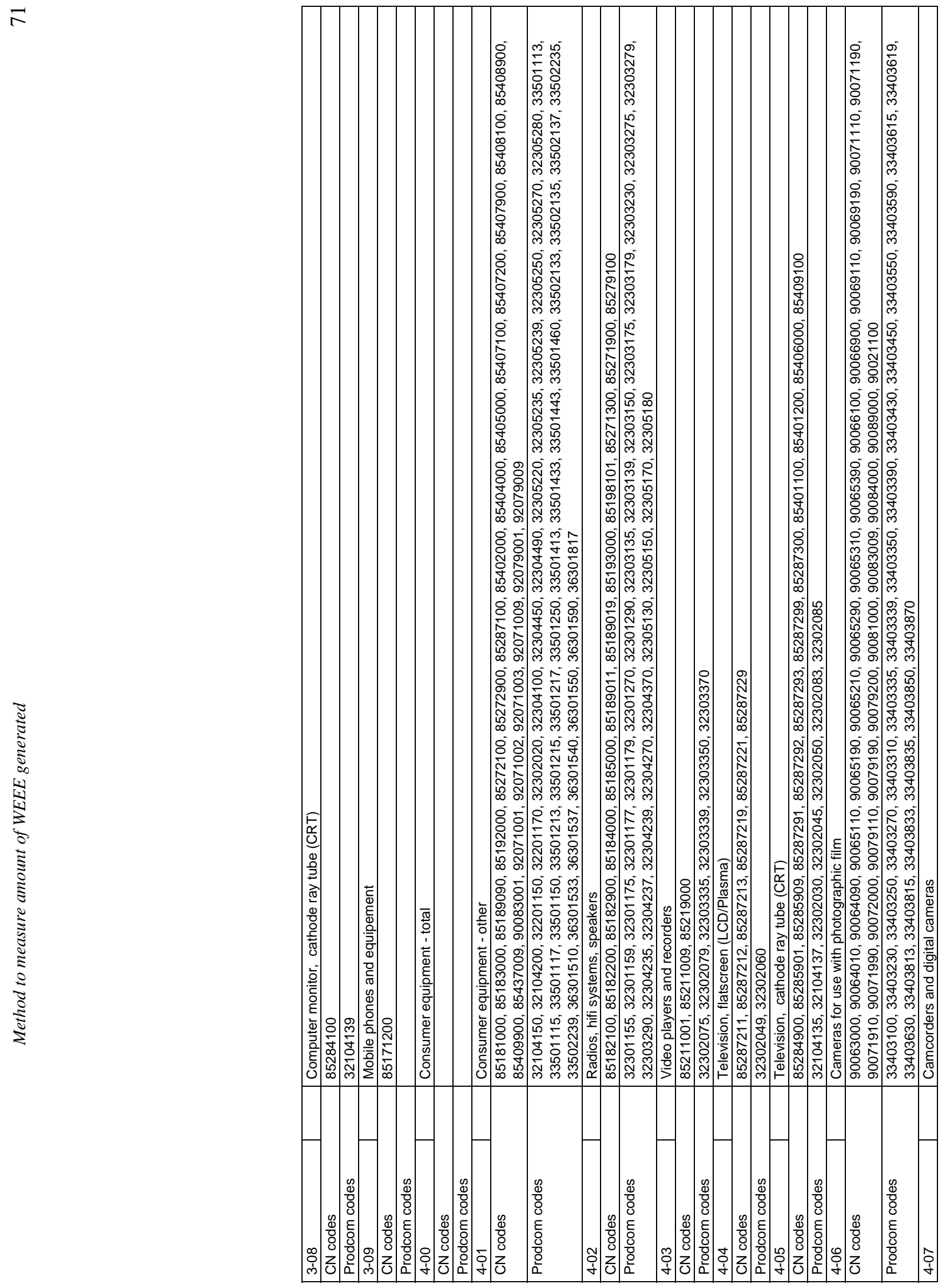




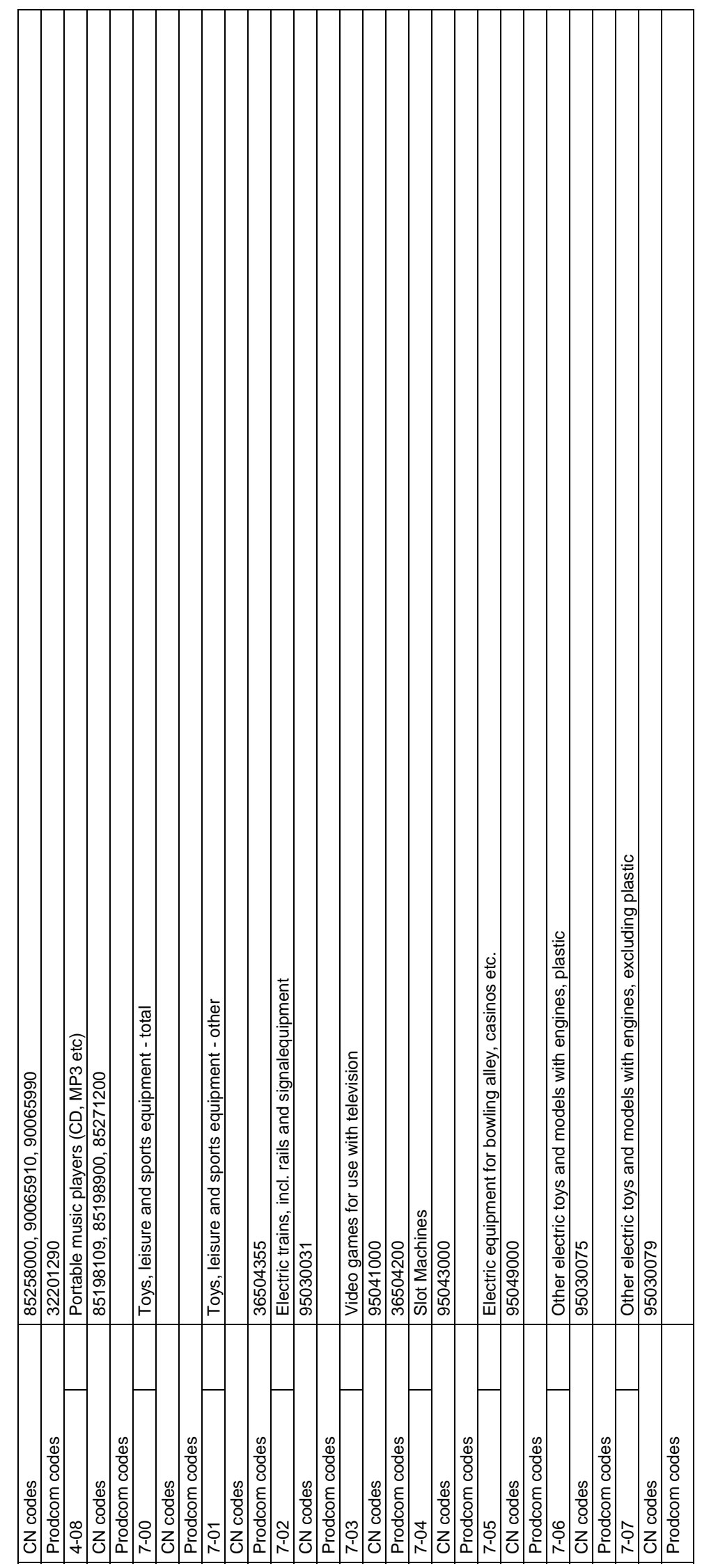




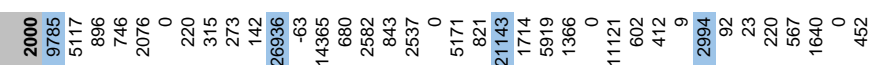

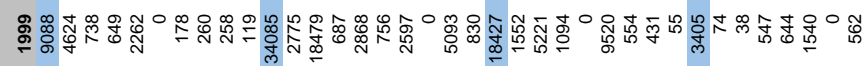

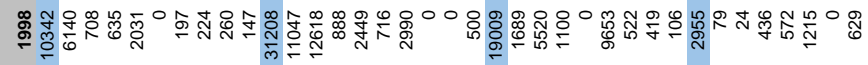

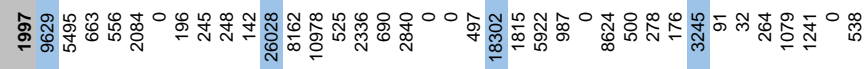

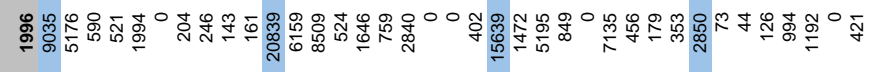

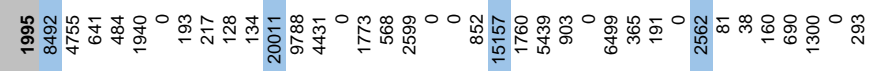

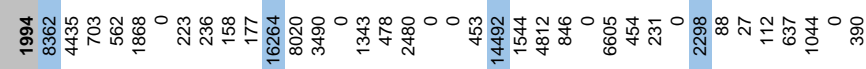

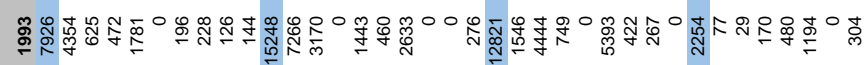

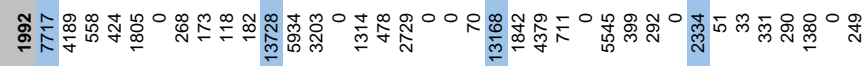

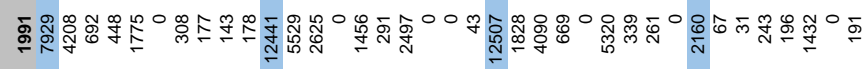

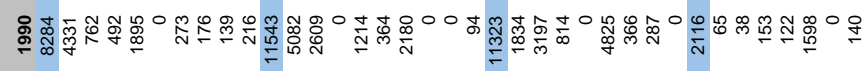

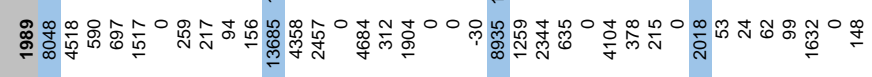

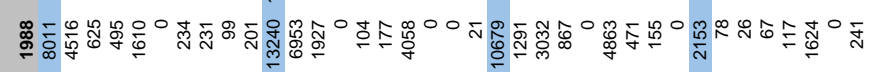

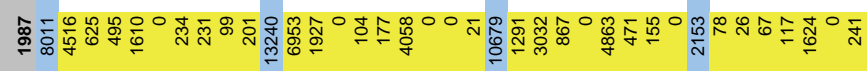

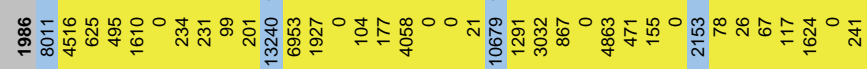

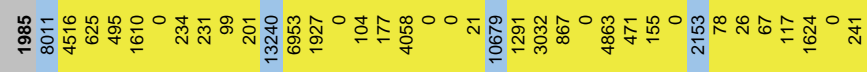

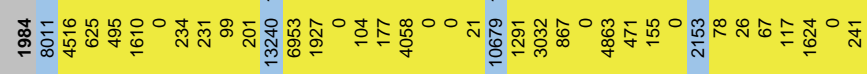

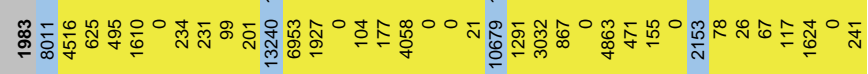

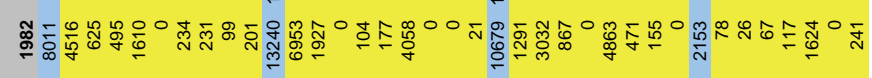

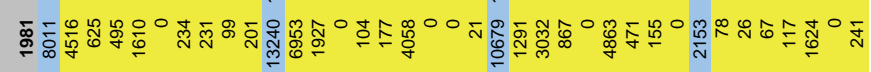

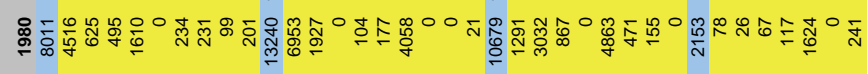

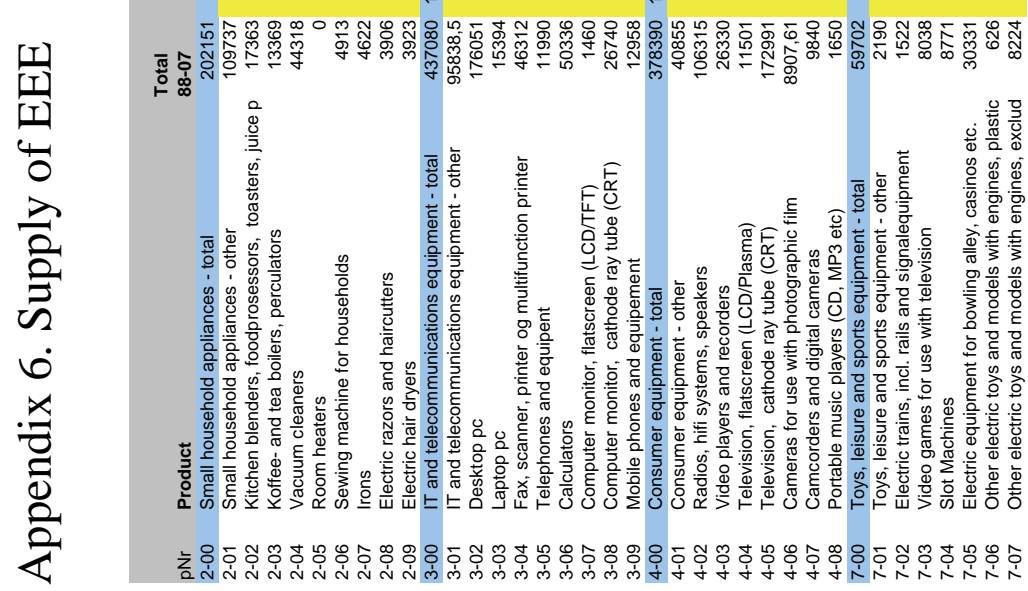




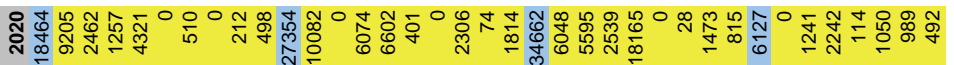

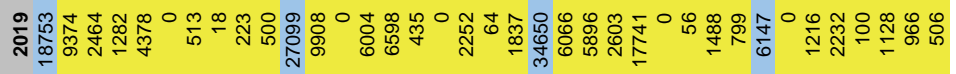

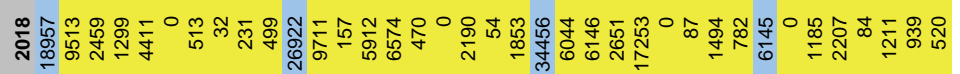

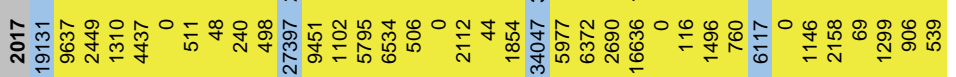

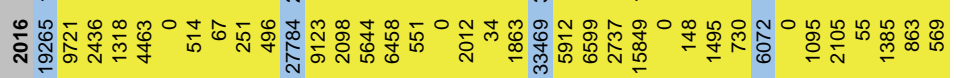

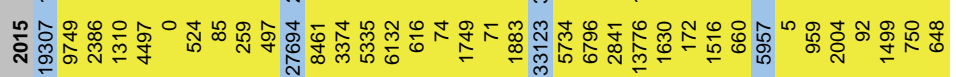

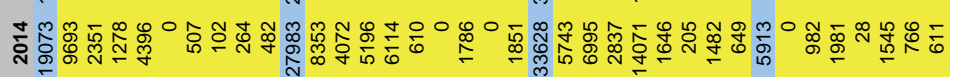

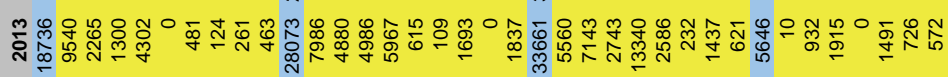

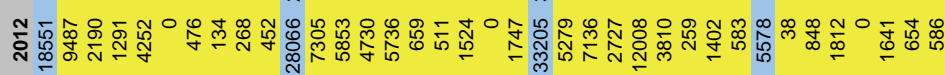

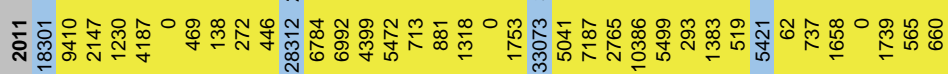

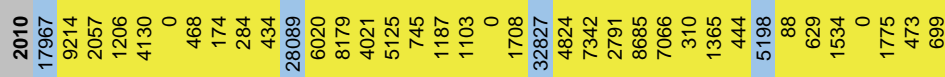

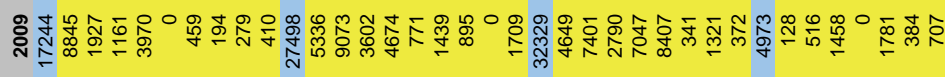

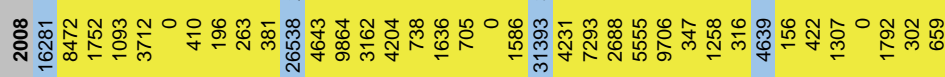

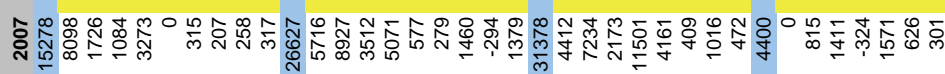

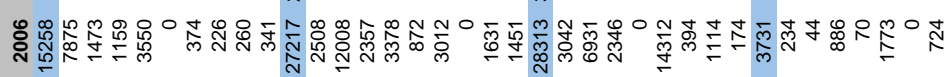

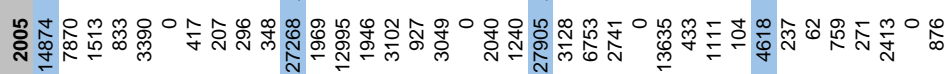

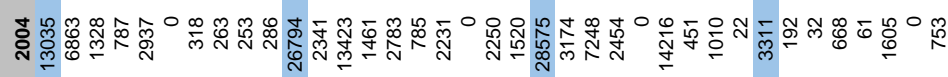

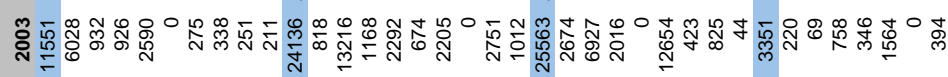

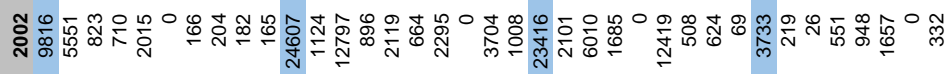

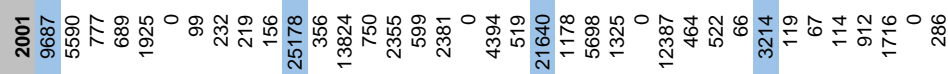

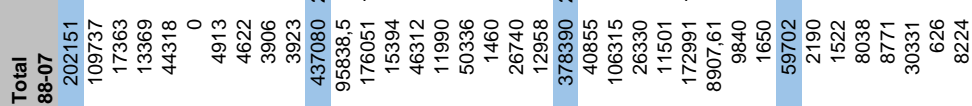

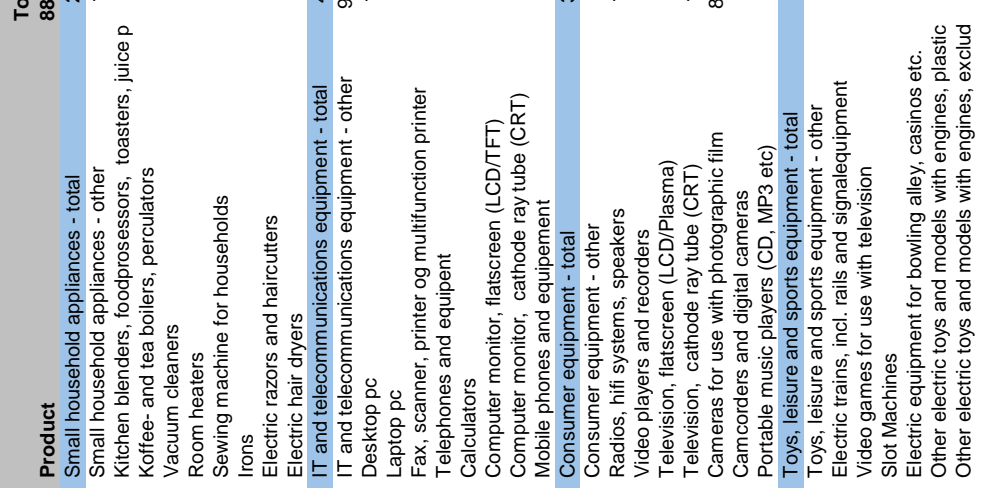

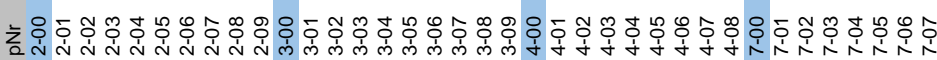


Appendix 7. Calculated WEEE

\begin{tabular}{|c|c|c|c|c|c|c|c|c|c|c|c|c|}
\hline $\mathrm{pNr}$ & Produkt & 2000 & 2001 & 2002 & 2003 & 2004 & 2005 & 2006 & 2007 & 2008 & 2009 & 2010 \\
\hline $2-00$ & Small household appliances - total & 8611 & 8854 & 9082 & 9333 & 9563 & 9864 & 10257 & 10805 & 11512 & 12304 & 13130 \\
\hline $2-01$ & Small household appliances - other & 4762 & 4920 & 5032 & 5140 & 5252 & 5395 & 5570 & 5841 & 6186 & 6570 & 6967 \\
\hline $2-02$ & Kitchen blenders, foodprosessors, toasters, juic & 660 & 667 & 688 & 715 & 759 & 805 & 866 & 960 & 1062 & 1184 & 1311 \\
\hline $2-03$ & Koffee- and tea boilers, perculators & 532 & 553 & 585 & 630 & 657 & 697 & 749 & 782 & 829 & 888 & 950 \\
\hline 2-04 & Vacuum cleaners & 1882 & 1926 & 1970 & 2013 & 2049 & 2104 & 2185 & 2300 & 2465 & 2648 & 2845 \\
\hline 2-05 & Room heaters & 0 & 0 & 0 & 0 & 0 & 0 & 0 & 0 & 0 & 0 & 0 \\
\hline $2-06$ & Sewing machine for households & 230 & 225 & 220 & 214 & 208 & 206 & 207 & 212 & 221 & 232 & 246 \\
\hline $2-07$ & Irons & 224 & 227 & 234 & 246 & 248 & 250 & 255 & 255 & 253 & 248 & 240 \\
\hline $2-08$ & Electric razors and haircutters & 168 & 187 & 207 & 227 & 235 & 238 & 237 & 240 & 246 & 253 & 259 \\
\hline 2-09 & Electric hair dryers & 153 & 149 & 146 & 148 & 155 & 169 & 188 & 215 & 250 & 282 & 311 \\
\hline $3-00$ & IT and telecommunications equipment - total & 20606 & 23419 & 25793 & 27200 & 27689 & 27474 & 27038 & 26592 & 26599 & 26792 & 27037 \\
\hline 3-01 & IT and telecommunications equipment - other & 7719 & 7394 & 6357 & 4938 & 3609 & 2571 & 1983 & 1812 & 1921 & 2399 & 3037 \\
\hline 3-02 & Desktop pc & 6834 & 8980 & 11105 & 12768 & 13705 & 13976 & 13843 & 13543 & 13183 & 12639 & 11935 \\
\hline $3-03$ & Laptop pc & 312 & 452 & 566 & 649 & 720 & 809 & 945 & 1150 & 1447 & 1838 & 2262 \\
\hline 3-04 & Fax, scanner, printer og multifunction printer & 1842 & 2058 & 2255 & 2381 & 2424 & 2423 & 2446 & 2549 & 2752 & 3100 & 3494 \\
\hline 3-05 & Telephones and equipent & 548 & 590 & 635 & 665 & 686 & 701 & 711 & 719 & 740 & 749 & 752 \\
\hline 3-06 & Calculators & 2669 & 2693 & 2697 & 2670 & 2619 & 2589 & 2521 & 2356 & 2410 & 2317 & 2173 \\
\hline 3-07 & Computer monitor, flatscreen (LCD/TFT) & 0 & 0 & 0 & 0 & 0 & 0 & 0 & 0 & 39 & 167 & 342 \\
\hline $3-08$ & Computer monitor, cathode ray tube (CRT) & 141 & 658 & 1489 & 2403 & 3133 & 3501 & 3495 & 3221 & 2770 & 2190 & 1583 \\
\hline 3-09 & Mobile phones and equipement & 540 & 594 & 689 & 726 & 792 & 904 & 1094 & 1242 & 1337 & 1393 & 1460 \\
\hline $4-00$ & Consumer equipment - total & 14422 & 15325 & 16285 & 17312 & 18452 & 19713 & 21137 & 22634 & 24070 & 25509 & 26878 \\
\hline 4-01 & Consumer equipment - other & 1651 & 1650 & 1648 & 1638 & 1669 & 1771 & 1949 & 2178 & 2426 & 2726 & 3050 \\
\hline 4-02 & Radios, hifi systems, speakers & 4585 & 4827 & 5045 & 5237 & 5406 & 5577 & 5772 & 5974 & 6174 & 6373 & 6561 \\
\hline 4-03 & Video players and recorders & 875 & 933 & 1005 & 1091 & 1204 & 1355 & 1552 & 1775 & 1980 & 2144 & 2279 \\
\hline 4-04 & Television, flatscreen (LCD/Plasma) & 0 & 0 & 0 & 0 & 0 & 0 & 0 & 113 & 212 & 735 & 1513 \\
\hline 4-05 & Television, cathode ray tube (CRT) & 6479 & 7049 & 7697 & 8425 & 9200 & 9964 & 10730 & 11351 & 11905 & 12008 & 11806 \\
\hline 4-06 & Cameras for use with photographic film & 432 & 450 & 470 & 486 & 497 & 499 & 496 & 487 & 474 & 458 & 440 \\
\hline 4-07 & Camcorders and digital cameras & 256 & 282 & 316 & 359 & 416 & 491 & 586 & 693 & 798 & 891 & 979 \\
\hline $4-08$ & Portable music players (CD, MP3 etc) & 144 & 135 & 104 & 76 & 61 & 54 & 52 & 64 & 101 & 173 & 249 \\
\hline $7-00$ & Toys, leisure and sports equipment - total & 2620 & 2758 & 2895 & 2993 & 3077 & 3167 & 3309 & 3530 & 3706 & 3906 & 4107 \\
\hline 7-01 & Toys, leisure and sports equipment - other & 78 & 79 & 84 & 92 & 106 & 127 & 146 & 160 & 172 & 167 & 158 \\
\hline 7-02 & Electric trains, incl. rails and signalequipment & 31 & 32 & 32 & 34 & 34 & 36 & 37 & 51 & 52 & 75 & 106 \\
\hline 7-03 & Video games for use with television & 217 & 263 & 311 & 332 & 353 & 404 & 479 & 581 & 680 & 815 & 962 \\
\hline 7-04 & Slot Machines & 563 & 608 & 646 & 685 & 704 & 685 & 641 & 581 & 495 & 398 & 308 \\
\hline 7-05 & Electric equipment for bowling alley, casinos etc & 1298 & 1303 & 1331 & 1376 & 1424 & 1469 & 1533 & 1608 & 1664 & 1703 & 1732 \\
\hline 7-06 & Other electric toys and models with engines, pla: & 0 & 0 & 0 & 0 & 0 & 0 & 0 & 26 & 46 & 129 & 219 \\
\hline 7-07 & Other electric toys and models with engines, exc & 434 & 472 & 490 & 475 & 457 & 446 & 473 & 524 & 597 & 618 & 621 \\
\hline
\end{tabular}

\begin{tabular}{|c|c|c|c|c|c|c|c|c|c|c|c|}
\hline $\mathrm{pNr}$ & Produkt & 2011 & 2012 & 2013 & 2014 & 2015 & 2016 & 2017 & 2018 & 2019 & 2020 \\
\hline $2-00$ & Small household appliances - total & 13948 & 14743 & 15493 & 16185 & 16801 & 17333 & 17784 & 18151 & 18435 & 18630 \\
\hline $2-01$ & Small household appliances - other & 7354 & 7722 & 8068 & 8388 & 8667 & 8905 & 9102 & 9256 & 9371 & 9441 \\
\hline $2-02$ & Kitchen blenders, foodprosessors, toasters, juic & 1441 & 1569 & 1695 & 1814 & 1922 & 2022 & 2110 & 2188 & 2256 & 2311 \\
\hline $2-03$ & Koffee- and tea boilers, perculators & 1011 & 1069 & 1117 & 1158 & 1197 & 1230 & 1256 & 1275 & 1288 & 1296 \\
\hline 2-04 & Vacuum cleaners & 3048 & 3252 & 3447 & 3628 & 3791 & 3933 & 4056 & 4160 & 4243 & 4305 \\
\hline 2-05 & Room heaters & 0 & 0 & 0 & 0 & 0 & 0 & 0 & 0 & 0 & 0 \\
\hline $2-06$ & Sewing machine for households & 263 & 283 & 304 & 326 & 347 & 368 & 389 & 408 & 425 & 440 \\
\hline $2-07$ & Irons & 229 & 218 & 206 & 192 & 177 & 162 & 146 & 130 & 114 & 97 \\
\hline $2-08$ & Electric razors and haircutters & 263 & 267 & 269 & 271 & 271 & 270 & 267 & 263 & 259 & 253 \\
\hline 2-09 & Electric hair dryers & 338 & 363 & 386 & 408 & 427 & 443 & 457 & 469 & 479 & 487 \\
\hline $3-00$ & IT and telecommunications equipment - total & 27262 & 27466 & 27697 & 27949 & 28180 & 28321 & 28348 & 28283 & 28144 & 27939 \\
\hline 3-01 & IT and telecommunications equipment - other & 3712 & 4372 & 5022 & 5655 & 6269 & 6855 & 7382 & 7865 & 8311 & 8716 \\
\hline 3-02 & Desktop pc & 11125 & 10286 & 9449 & 8593 & 7691 & 6746 & 5792 & 4839 & 3889 & 2944 \\
\hline $3-03$ & Laptop pc & 2680 & 3077 & 3451 & 3808 & 4149 & 4465 & 4751 & 5010 & 5243 & 5450 \\
\hline 3-04 & Fax, scanner, printer og multifunction printer & 3885 & 4252 & 4595 & 4917 & 5220 & 5495 & 5732 & 5939 & 6118 & 6268 \\
\hline 3-05 & Telephones and equipent & 753 & 750 & 744 & 734 & 719 & 699 & 678 & 655 & 628 & 599 \\
\hline 3-06 & Calculators & 1987 & 1773 & 1545 & 1321 & 1096 & 859 & 640 & 447 & 291 & 176 \\
\hline 3-07 & Computer monitor, flatscreen (LCD/TFT) & 533 & 715 & 883 & 1047 & 1212 & 1372 & 1518 & 1652 & 1777 & 1894 \\
\hline $3-08$ & Computer monitor, cathode ray tube (CRT) & 1034 & 602 & 309 & 137 & 52 & 19 & 13 & 17 & 26 & 34 \\
\hline 3-09 & Mobile phones and equipement & 1553 & 1639 & 1701 & 1737 & 1773 & 1809 & 1841 & 1859 & 1862 & 1856 \\
\hline $4-00$ & Consumer equipment - total & 28144 & 29287 & 30295 & 31157 & 31874 & 32452 & 32880 & 33186 & 33418 & 33611 \\
\hline 4-01 & Consumer equipment - other & 3387 & 3718 & 4034 & 4330 & 4609 & 4868 & 5099 & 5303 & 5478 & 5627 \\
\hline 4-02 & Radios, hifi systems, speakers & 6733 & 6881 & 6999 & 7083 & 7135 & 7155 & 7142 & 7097 & 7020 & 6911 \\
\hline $4-03$ & Video players and recorders & 2394 & 2493 & 2576 & 2642 & 2690 & 2727 & 2754 & 2767 & 2767 & 2753 \\
\hline 4-04 & Television, flatscreen (LCD/Plasma) & 2500 & 3643 & 4888 & 6188 & 7501 & 8807 & 10034 & 11202 & 12306 & 13342 \\
\hline 4-05 & Television, cathode ray tube (CRT) & 11337 & 10653 & 9803 & 8827 & 7769 & 6655 & 5556 & 4482 & 3477 & 2585 \\
\hline 4-06 & Cameras for use with photographic film & 421 & 400 & 379 & 356 & 332 & 308 & 282 & 255 & 228 & 200 \\
\hline 4-07 & Camcorders and digital cameras & 1060 & 1135 & 1203 & 1261 & 1313 & 1358 & 1397 & 1428 & 1453 & 1470 \\
\hline 4-08 & Portable music players (CD, MP3 etc) & 312 & 363 & 414 & 468 & 524 & 573 & 615 & 653 & 689 & 724 \\
\hline $7-00$ & Toys, leisure and sports equipment - total & 4313 & 4518 & 4719 & 4911 & 5091 & 5271 & 5435 & 5584 & 5714 & 5823 \\
\hline 7-01 & Toys, leisure and sports equipment - other & 148 & 136 & 122 & 106 & 88 & 70 & 53 & 39 & 29 & 21 \\
\hline 7-02 & Electric trains, incl. rails and signalequipment & 148 & 199 & 259 & 326 & 398 & 477 & 555 & 633 & 709 & 783 \\
\hline $7-03$ & Video games for use with television & 1113 & 1255 & 1385 & 1507 & 1621 & 1731 & 1828 & 1915 & 1990 & 2057 \\
\hline 7-04 & Slot Machines & 229 & 163 & 111 & 73 & 46 & 32 & 26 & 27 & 31 & 39 \\
\hline 7-05 & Electric equipment for bowling alley, casinos etc & 1752 & 1763 & 1763 & 1750 & 1726 & 1695 & 1657 & 1612 & 1559 & 1499 \\
\hline 7-06 & ther electric toys and models with engines, pla & 301 & 372 & 439 & 509 & 578 & 646 & 703 & 755 & 805 & 853 \\
\hline 7-07 & Other electric toys and models with engines, exc & 623 & 630 & 639 & 641 & 634 & 621 & 613 & 603 & 590 & 572 \\
\hline
\end{tabular}

